\title{
Subsidized labour and firms
}

Investment, profitability, and leverage

Isaac Marcelin, ${ }^{1}$ Daniel Brink, ${ }^{2}$ David Oluwatosin Fadiran, ${ }^{3}$ and Hammed Adedeji Amusa ${ }^{4}$

June 2019 
Abstract: Employing the difference-in-differences technique, this study examines the impact of the Employment Tax Incentive programme on a large sample of South African firms from 2011 to 2016. It finds that programme firms expanded investments by 4.8 per cent, and profits by 5.7 per cent. Consistent with the financial constraints theory, leverage rose by 6.63 per cent at smaller ETI firms, which are plagued with information asymmetry problems. Results imply both cost and liquidity mechanisms whereby the policy defrayed labour costs to boost profits and cash flows. Triple difference-in-difference estimates reveal that the policy had stronger effects at financially constrained firms. With important implications for labour markets and fiscal policies, the results suggest that well-designed youth wage subsidy policy schemes have the potential to enhance the prospects both of firms and of the economy more broadly.

Keywords: labour subsidy, investment, profitability, leverage

JEL classification: D22, F14, H32, J32, O47

Acknowledgements: We would like to thank the South African Revenue Service (SARS), UNUWIDER, and the South African National Treasury for their support. We thank Charl van Schoor and Amina Ebrahim for guidance and help with the data. We are thankful to the participants in the UNUWIDER workshop in Pretoria for their invaluable comments. Although the outputs have been verified to preserve the anonymity of firms and individuals involved in the data, the results have not been sanctioned by either SARS or the National Treasury. All errors, omissions, and deficiencies remain ours.

\footnotetext{
1 School of Business, Management and Technology, University of Maryland Eastern Shore, Princess Anne, MD, USA, corresponding author: imarcelin@umes.edu; ${ }^{2}$ Department of Economics, University of Pretoria, Hatfield, Pretoria, South Africa, danebrink08@gmail.com; 3 School of Economics, University of Cape Town, Rondebosch, Cape Town, South Africa, alamu3@gmail.com; ${ }^{4}$ Macroeconomic, Debt Sustainability and Forecasting Division, Research Department (ECMR), African Development Bank (AfDB), Abidjan, Côte d'Ivoire, h.amusa@afdb.org.
}

This study has been prepared within the UNU-WIDER project 'Southern Africa-Towards Inclusive Economic Development (SA-TIED)'.

Copyright (C) UNU-WIDER 2019

Information and requests: publications@wider.unu.edu

ISSN 1798-7237 ISBN 978-92-9256-684-5

https://doi.org/10.35188/UNU-WIDER/2019/684-5

Typescript prepared by Luke Finley.

The United Nations University World Institute for Development Economics Research provides economic analysis and policy advice with the aim of promoting sustainable and equitable development. The Institute began operations in 1985 in Helsinki, Finland, as the first research and training centre of the United Nations University. Today it is a unique blend of think tank, research institute, and UN agency — providing a range of services from policy advice to governments as well as freely available original research.

The Institute is funded through income from an endowment fund with additional contributions to its work programme from Finland, Sweden, and the United Kingdom as well as earmarked contributions for specific projects from a variety of donors.

Katajanokanlaituri 6 B, 00160 Helsinki, Finland

The views expressed in this paper are those of the author(s), and do not necessarily reflect the views of the Institute or the United Nations University, nor the programme/project donors. 
Academics and policymakers have long demonstrated great interest in how government interventions such as taxes, subsidies, and regulations affect firm performance. In 2014, to promote youth employment, the South African government introduced the Employment Tax Incentive (ETI) programme. In February 2019, the government extended the programme for ten years until February 2029. ${ }^{1}$ Through this direct intervention in the labour market, firms are granted a tax credit for hiring young individuals (Ebrahim et al. 2017), cutting the costs of hiring this hardto-employ group by up to 50 per cent (Ebrahim et al. 2017; Levinsohn et al. 2014). Ancillary to potential near-term improvements in employment outcomes, the policy of shifting a portion of the labour costs to taxpayers may yield significant economic benefits for participating firms in terms of investment growth, profitability, and debt capacity.

Many firms across the industry spectrum may be unable to acquire new machinery and technology out of free cash flows and accumulated reserves, inasmuch as steep labour costs depress a firm's profits; this, in turn, hinders the firm's ability to expand across different asset classes, thereby holding back expansion. Labour-intensive firms with investment opportunities and capacity underutilization may benefit from increasing employment through the wage subsidy. On the other hand, the ETI may choke productivity and efficiency, resulting in resource misallocation.

The ETI may impact firm performance through a number of channels. A priori, subsidized labour drives a wedge between the cost of internal and external finance. Cheaper internal finance lowers a firm's investment cash-flow sensitivities (Lyandres 2007), affecting its balance sheet and asset allocation, and the bottom line. Finance theory suggests that a stronger balance sheet combined with higher levels of internal financial resources allows firms to overcome lack of access to external finance and under-investment problems.

Whereas ETI utilization creates a quasi-natural experiment setting suitable for testing how firmlevel outcomes respond to labour market policies, growth in fixed assets, in particular, may react slowly to the policy because investment is a much noisier outcome variable. A priori, with lumpy investment, the experiment may fail to provide sufficient statistical power in analysing the capital expenditure response. Thus, analysing profitability and leverage responses may result in a more encompassing view of the effect of the policy on firms.

This study uses the difference-in-differences (DiD) technique to analyse the effect of the ETI on firms. Although it is possible to quantify the policy's effect on firms in any industry, the stimulus may be more impactful in labour-intensive than in capital-intensive industries, making its potential impact a multifaceted inquiry of empirical interest. The policy's impacts are relevant for adopters, as well as for countries facing structural imbalances in labour markets with capacity underutilization at the corporate level. This study enquires whether the ETI affects firms' balance sheet and performance rather than simply providing a windfall to participating firms or merely distorting resource allocation. Does the ETI affect the economy beyond promoting employment among hard-to-employ groups? If the ETI is associated with firms' expansion, then there will be a positive correlation between the ETI, capital expenditures (CAPEX), and firms' profits. However, the relationship between the policy and debt ratios is less straightforward: greater access to credit may help in the acquisition of new profitable investments, but the debt burden may reduce profits.

\footnotetext{
${ }^{1}$ Section 102 of the Taxation Laws Amendment Act, No. 23 of 2018.
} 
Despite important results, from rigorous methodological techniques in the extant literature, on the economic effect of tax subsidy (Ebrahim et al. 2017; Hamersma 2008; Katz, 1996; Levinsohn et al. 2014; Perloff and Wachter 1979), microeconomic processes may provide a deeper understanding of the channels through which labour policies affect the economy. This study intends to bridge this important perceived research gap by analysing the effect of the ETI on some of the firms' fundamentals. We find that for ETI firms, investments expanded by 4.8 per cent, profits by 5.7 per cent, and leverage by 6.63 per cent. Consistent with the financial constraints theory and the costs effect, the policy has stronger effects in financially constrained firms.

There is a paucity of micro-evidence in the extant literature with respect to labour subsidy and firm-level outcomes. This paper contributes to the literature on the fiscal policy/finance nexus in several ways. First, it uses an exclusive database to examine the policy's effects. It takes advantage of the natural split between the subsidy takers and non-takers to derive the counterfactuals. The methodology and the richness of data allow the exploration of many channels through which the subsidy affects firms. More importantly, the results provide evidence of how a government programme affects firms' performance with respect to capital purchases, profits, and leverage. With programme firms growing faster than non-programme firms, and considering the policy's effect of easing access to finance for small and credit-constrained firms, many countries with developing financial markets may design growth-enhancing labour policies contingent upon their institutional settings. With important implications for labour markets and fiscal policies, the results suggest that well-designed youth wage subsidy programmes have the potential to enhance the prospects of firms and of the economy as a whole.

The remainder of the paper is partitioned as follows. The next section presents the institutional background to the policy. The third section briefly discusses the related literature. The fourth section presents the methodology. The fifth section describes the data. The sixth section analyses the results. The last section concludes.

\section{Policy background}

In the post-1994 period, South Africa has made notable strides in expanding the delivery of social services through the government's pro-poor spending and redistribution policies. However, the country still faces high levels of inequality and poverty. In the first decade following the democratic transition, its longest period of steady economic growth coincided with a period of rising unemployment rates. Seekings (2007) notes that South Africa's unemployment exhibited a steady rise for most of the post-1994 period, peaking in early 2003 at 31.2 per cent (active job-seekers) and 42.5 per cent (job-seekers plus the long-term unemployed who have given up looking for work). The combination of steady economic growth, rising unemployment rates, and stagnant employment growth led the then-president Thabo Mbeki to lament that:

[S]outh Africa has two parallel economies: the First Economy is modern, produces the bulk of our country's wealth, and is integrated within the global economy; the Second Economy-the Marginalized Economy-is characterized by underdevelopment, contributes little to the GDP, contains a big percentage of our population, incorporates the poorest of our rural and urban poor, is structurally disconnected from both the First and the global economy, and is incapable of selfgenerated growth and development. (Mbeki 2003) 
Since $1994,{ }^{2}$ several iterations of macroeconomic policies and reforms have been adopted that have expanded income and employment opportunities for previously disadvantaged South Africans. Also, the country emerged from the 2008/09 financial crisis with low growth and longstanding structural weaknesses, further constraining new job creation and limiting the economy's prospects of lowering the high levels of poverty and unemployment. The burden of South Africa's unemployment is inordinately borne by its youth, who represent 36 per cent of South Africa's population (Statistics South Africa 2016). In 2013, Statistics South Africa estimated that over 30 per cent of those aged 15-24 were not in employment, education, or training, implying that almost one in three South African youths were disengaged from the labour market, with the youth unemployment rate hovering around 63 per cent of the youth labour force (or a total of 3.2 million individuals).

Policy measures addressing youth unemployment have included a range of macro- and micro-level interventions. ${ }^{3}$ The government's initial set of macro-level policies were mainly demand-side interventions in the form of public employment schemes emphasizing the provision of work opportunities and income support to poor and unemployed people. The public employment programme is underpinned by two initiatives, namely the Expanded Public Works Programme (EPWP) and the Community Works Programme (CWP).

The National Treasury promoted a youth wage subsidy in 2011 by advocating that in an environment where limited work experience and high costs of hiring (and firing) new staff work against youth hires, a wage subsidy can lower the relative cost of hiring a young person while leaving the wage the employee receives unaffected (National Treasury 2011). In 2013, to address such structural imbalances the government enacted the ETI policy, which took effect in 2014. By lowering hiring costs, the subsidy mitigates the financial risk associated with hiring inexperienced, low-skilled youth, and raises the long-term employment prospects of young hires who gain work experience, via on-the-job training, during the period of subsidized work. Several studies, including Levinsohn et al. (2014) and Levinsohn and Pugatch (2014), concur that a youth wage subsidy has the potential to positively enhance employment prospects for young people. The main component of the policy scheme is a wage subsidy targeting hard-to-employ youth, covering up to 50 per cent of their wage. The policy seeks to encourage private employers to create jobs for young people from 18 to 29 years old, earning up to R6,500. ${ }^{4}$ However, individual employees are qualified for up to two years of claims. Firms that employ the voucher-bearers can claim the subsidy when filing their taxes. Important financial benefits may accrue for firms in labour-intensive industries.

The subsidy was scheduled to be phased out after three years, but was extended for two additional years. Five years into the programme, in February 2019, the government decided to extend the ETI for ten additional years until 29 February 2029, making its evaluation highly relevant and topical. The South African Revenue Services (SARS) provides guidance to taxpayers on the administration of the policy. Nevertheless, many issues remain pertaining to the management of

\footnotetext{
${ }^{2}$ From 1994, the Reconstruction and Development Programme (RDP) became the official macroeconomic policy of the new democratic government. This was followed by the Growth, Employment and Redistribution (GEAR) programme in 1996, the Accelerated and Shared Growth Initiative (AsgiSA) framework in 2006, and the New Growth Path (NGP) in 2010.

${ }^{3}$ De Lannoy et al. (2018) provide an excellent outline of the policy development regarding youth employment in South Africa since the early 1990s.

${ }^{4}$ Per Clause 5 of the Rates and Monetary Amounts and Amendment of Revenue Laws Bill, published on 20 February 2019.
} 
the ETI. These include non-compliance, outright fraud, incorrect payroll mapping, and over- and underpayments (Ebrahim et al. 2017; Levinsohn et al. 2014). ${ }^{5}$

\section{Brief overview of the literature}

Policy-crafters in both developed and developing countries implement labour policies seeking to curtail unemployment. Examining the Targeted Jobs Tax Credit (TJTC) programme in the USwhich offered wage subsidies of up to US $\$ 6,000$ or 50 per cent the first year, and 25 per cent of second-year wages, for vulnerable and economically disadvantaged workers such as youth, veterans, workers on public assistance, and disabled workers-Katz (1998) documents a net employment effect of 7.7 per cent. Analysing a similar programme for the Argentinean labour market whereby workers' wages were subsidized by 50 per cent for 18 months, Galasso et al. (2001) report that the programme had a significant impact for women and youth. Evidence dating back to Bishop (1981) shows that the New Jobs Tax Credit (NJTC), a US programme offering a 50 per cent tax credit for the first US $\$ 4,200$ of wages per worker, raised employment by $0.2-0.8$ per cent.

Although using a sample of Irish firms and investigating the effects of government grants to firms, Girma et al. (2008) find a positive employment effect at domestic-owned firms; Mühlau and Salverda (2000) counter that the measure did not significantly increase the growth of employment in any particular industry. Ebrahim et al. (2017) and Levinsohn et al. (2014) provide insights on the merits of the ETI policy with respect to the South African labour market. Evaluating a similar programme employing US data, Perloff and Wachter (1979) report a modest utilization rate of just 3 per cent increase in employment at programme firms. Several OECD (Organisation for Economic Co-operation and Development) nations have experiences with private sector employment subsidies (Hamersma 2008; Katz 1996).

In practice, ETI firms receive a stimulus through reduced production costs, which may result in improved profitability, lower liquidity risk, and greater investible resources to finance growth through superior capability to mobilize finance and exploit economies of scale. When competitive forces are at play, Perloff and Wachter (1979) imply, a policy lowering a firm's wage induces a shift away from capital towards labour within the firm, and from capital- to labour-intensive firms. Saez et al. (2019) investigate the firm-level effects of an employment tax windfall in Sweden offered for hiring young workers - a rate cut from 31 per cent to 15 per cent for young workers (aged 26 or less). They report that firms with a higher proportion of targeted workers expanded after the reform: employment, capital, sales, value added, and profits all increased. Whereas Yagan (2015) shows that the US dividend tax cut of 2003 had no significant effect on business activities in terms of either investment growth or employee compensation, Chetty and Saez (2005) affirm that it had a strong positive effect on dividend payments.

Kaunitz and Egebark (2019) examine the effect of the payroll tax reform on various firm outcomes in 2007, and show no impact on profits, a negligible effect on gross investments, and a negative but insignificant effect on productivity. Korkeamäki (2011) studies a payroll tax reduction experiment in Finland introduced in some regions (treatment) in 2003, and detects no significant effect on firm profits. Using a similar set-up, in Bennmarker et al. (2009) and Korkeamäki and Uusitalo (2009) (for a sample of Swedish and Finnish firms) and in Anderson and Meyer (1997) (for US firms), no clear consensus emerges on the effects on firms of slashing payroll tax rates.

\footnotetext{
${ }^{5}$ Ebrahim et al. (2017) provide detailed description of the management of the policy.
} 
While Saez et al. (2019), utilizing Swedish firms, advance the view that credit-constrained firms benefit more from employment tax cuts, Zwick and Mahon (2017) argue that US temporary tax incentives for investment raised investments by a whopping 10.4 per cent between 2001 and 2004 and 16.9 per cent between 2008 and 2010, with the effect particularly strong at small firms. They suggest a liquidity effect whereby small and credit-constrained firms generated higher cash flows. Nonetheless, evidence of the effects of employment subsidies on firms' outcomes remains scarce. Card and Krueger (1995) attempt to address the issue of the effect of minimum wage increase on firms' profits using stock market valuations as a proxy for profits, and report that minimum wage increases compel investors to adjust firms' valuation downwards. Draca et al. (2011) observe a significant decline in profits and an uptick in labour costs, attributed to a higher minimum wage scheme, which does not percolate employment or productivity. Incidentally, if employment tax credit enhances profitability (Saez et al. 2019), a temporary stimulus allowing firms to write off investment purchases boosts economic activities (Zwick and Mahon 2017); thus, it can be conjectured that the ETI is associated with firms' expansion, profitability, and debt capacity.

If the policy successfully raises firms' profits by curtailing labour costs, participants' liquidity position will increase, allowing them to increase investment purchases through either retained earnings or greater access to external finance. In particular, small firms, characterized by information asymmetry, or financially and informationally challenged companies may become more appealing to capital suppliers if their fundamentals improve as a result of ETI take-up. Nevertheless, these firms may also lack the managerial ability to learn about the policy, and general internal attitudes coupled with external factors may thwart their participation in the programme.

\section{$4 \quad$ Methodology}

Assuming that accepting the ETI is an exogenous event well distributed across firms and regions, and that fluctuations in the performance of ETI firms move in tandem with those of non-ETI firms, intrinsically, the outcomes of ETI and non-ETI firms exhibit similar paths over time, and what differs is that some firms adhere to the programme while others do not. This natural split offers a unique opportunity to assess the effects of the policy on the hypothesized outcomes exploiting the DiD technique, employing non-ETI firms as counterfactuals.

To estimate the effect of ETI on firms, we employ the propensity-score matching (PSM) technique using a number of observed firms' characteristics obtained from the firms' balance sheets and income statements. ETI and non-ETI claimants are matched using their pre-treatment attributes to determine the probability of a firm taking up the wage subsidy. PSM models match observations based on the probability of undergoing the treatment (Lawrence et al. 2011). PSM populates samples wherein ETI and non-ETI claimants are similar. Algebraically, matching does not require functional form assumptions (Bryson et al. 2002; Li and Prabhala 2007); rather, it mitigates the potential impact of non-linearities in estimating the treatment effects when the underlying functional form is non-linear (Lawrence et al., 2011).

Cram et al. (2009) highlight that matching reflects a trade-off between identifying the treatment effects and generalizing the results to the full population. We use a logit model to estimate the probability of taking up the ETI. Bryson et al. (2002) advance the suggestion that in the single treatment case, the probit and logit models usually yield similar results, rendering the choice between them immaterial. A key advantage is that matching models do not require exclusion restrictions, and the general rule is to include a comprehensive list of attributes when estimating the propensity score (Lawrence et al. 2011; Li and Prabhala 2007). We estimate the propensity scores for ETI firms using the following specification: 


$$
E T I_{i t}=\alpha_{i}+\mathbf{B} \boldsymbol{C H} \boldsymbol{A} \boldsymbol{R}_{i t}+I N D_{F E}+Y E A R_{F E}+\varepsilon_{i t}
$$

Where $i$ and $t$ index the firm and time, respectively. CHAR represents a vector of firm attributes such as: SIZE, the natural log of the firm's total assets; LEVERAGE, the firm's debt, deflated by total assets; PROFIT, the firm's ROA or net profit to total assets; and CURNT, the firm's liquidity level or ratio of current assets to current liabilities. We proceed to estimate the p-scores and assess whether the variables are predictive of a firm taking up the ETI. We evaluate the propensity scores by inspecting the common support. We restrict the matching to firms sharing propensity score values for the ETI and the donors' groups. We then match ETI firms with contributors with the closest scores. Although Dehejia and Wahba (1999) maintain that nearest neighbour, caliper, and kernel matchings allow for multiple comparators for each treatment group member, Bryson et al. (2002) note that all three yield the same results when using large data sets such as ours. We evaluate some critical aspects of the matching procedure, such as by testing the balance for the original and the matched samples based upon the firms' attributes. Equation (1) seems successful in forming a balanced sample of ETI and non-ETI firms: all of the control variables in the propensity-score matched sample, except for DIVIDENDS, are insignificantly different at the conventional level between the two groups of firms. In other terms, except for DIVIDENDS, as shown in Table 3, post-matching means test differences fail to reject the null hypothesis of equal means between ETI and non-ETI firms for all of the matching characteristics. The magnitude of bias reduction after matching was statically significant. ${ }^{6}$

\subsection{Measuring the ETI effect}

We use OLS and firm fixed effects to estimate the effect of the ETI on three firm-level outcomes: growth, profitability, and debt capacity-employing the DiD technique on the full and the matched samples. To test whether ETI firms expand faster than their non-ETI peers, for instance, the following specification was employed:

$$
Y_{i t}=\alpha_{i}+\boldsymbol{\delta} E T I_{i t}+\mathrm{B} \boldsymbol{X}_{i t}+Y E A R_{F E}+\varepsilon_{i t}
$$

where $i$ and $t$ index the firm and the year, respectively. Consistent with prior research, we create a dummy variable, ETI_FIRM (not shown) that takes on a value of 1 for each eligible firm that took up the voucher, and a value of 0 if the firm declined the voucher, for all years. We include a POST_ETI dummy, an indicator that takes on a value of 1 for the years 2014 to 2016, and 0 for prior years. To capture the counterfactual effect, $\boldsymbol{\delta}$, the means difference between treated and donor groups, we include ETI, the interaction between ETI_FIRM and POST_ETI. $\boldsymbol{X}$ is a vector of firms' control variables, which include SIZE, LEVERAGE, and CURNT, among other indicators. The outcome variables are the growth rate in investment or capital expenditures, CAPEX, modelled as (FIXED_ASSETS $s_{t}-$ FIXED_ASSETS $\left.t_{t-1}\right) /$ FIXED_ASSETS $S_{t-1}$; PROFITS; and LEVERAGE. The dependent variable and the conditioning set vary across specifications and tables. The variables are defined in Table 1.

Prohibitive labour costs hinder a firm's ability to invest in productivity-enhancing technologies to boost production levels. Inasmuch as private employers take up the subsidy, the effect may vary with respect to the firm's resource endowments. Specifically, firms in sectors such as mining, hospitality, agriculture, hotels, and restaurants may briefly gain in productivity even when they are slow to acquire new technology. Thus, a firm's response may be a function of (1) resource

\footnotetext{
${ }^{6}$ Additional descriptive statistics on a more comprehensive set of matching characteristics may be obtained on request.
} 
endowments (labour, capital, and intangible intensities); (2) size (large, medium, or small); and (3) industry sector. As a result, our specifications control for firm and industry unobserved effects.

Table 1: Variable descriptions

\begin{tabular}{|c|c|}
\hline Variable & Description \\
\hline Tobin's Q & $\begin{array}{l}\text { The sum of the market value of equity and the book value of liabilities over the } \\
\text { book value of total assets for a given firm in a particular year }\end{array}$ \\
\hline CASHFLOW & Net income plus depreciation deflated by total assets \\
\hline SIZE & Natural log of a firm's total assets \\
\hline CAPEX & Capital expenditures, or net fixed assets \\
\hline GROWTH & $\begin{array}{l}\text { Fixed assets/total assets, or } \\
\qquad\left(\text { fixed }_{\text {assets }}-\text { fixed assets }\right. \\
t-1\end{array}$ \\
\hline PROFIT & Net income/total assets \\
\hline EMPLOYMENT & Natural logarithm of number of employees per firm \\
\hline LEVERAGE & A firm's debt-to-equity ratio \\
\hline CASH_HOLDING & Log of cash and near-cash items \\
\hline EBITDA & $\begin{array}{l}\text { Value of a firm's income derived from its operations, computed as revenue less } \\
\text { operating expenses }\end{array}$ \\
\hline DIVIDENDS & Log of the dividend paid \\
\hline CURNT & Current assets/current liabilities \\
\hline GDP & Gross domestic product \\
\hline Industry sector & Two-digit industry sector \\
\hline
\end{tabular}

Source: Authors' construction based on IRP5 data, made available through the joint SARS/National Treasury/UNU-WIDER initiative.

\subsection{Identification strategy}

As the wage subsidy lowers the relative cost of employing the targeted inexperienced youth, demand increases for these workers by certain firms. At the firm level, a lower wage bill is associated with lower production costs. With declining average costs, the firm's production becomes cheaper-leading to higher profitability, and allowing the firm to expand through either higher retained earnings or greater access to external finance. As the firm becomes more profitable, its ability to purchase capital goods increases, which, as a corollary, boosts productivity. In the traded sector, for example, as a firm's productivity increases, price competition and demand schedule should drive aggregate sales, enhancing the country's trade balance.

Imagine two groups of firms intending to expand, but operating in industries with dissimilar resource endowments. Although both groups would benefit from cheap labour, only one group utilizes the wage subsidy. Without the wage subsidy, hiring patterns and cost structures for firms in the hiring group would remain consistent with their capital budgeting plan. As the subsidy kicks in, the group that decides to utilize cheap labour witnesses a decline in average costs. In contrast, the non-ETI group maintains its historical isoquants. Matching the two groups' average outcomes based on their pre-policy characteristics, including industry sector and size, can produce robust estimates.

The effect of the ETI on firm-level outcomes using cross-sectional setting may be affected by a number of factors. In particular, the estimates may be biased if enough financially distressed firms took up the policy primarily to obtain a windfall to enhance their bottom line. This may be circumvented by observing firms' characteristics before and after the policy as well as their propensity to claim the wage voucher. In other words, this bias can be mitigated by observing firms' performance (1) in an ETI-free environment and (2) in the ETI environment, and by 
stratifying the analysis. However, this may be considered as a behavioural problem (a scenario hard to observe) rather than one of omitted variables.

Although exploiting within-firm variability requires a group of firms which have not taken up the wage voucher-allowing us to estimate the counterfactuals of investment rates, profitability, and debt capacity of the affected firms in the absence of the policy-this assumption may be too strong. Somehow, on average, firms in the treatment group may have other skills (hard-to-observe scenario) which their peers do not have, enabling them to obtain timely information relative to the policy and its likely benefits. Nevertheless, whatever positive effect accrued through utilizing the programme is measurable, in such a large sample any managerial skills presented by a given ETI firm are likely to be either temporary or matched by those of the average firm in the donor cohort. Therefore, changes in a firm's growth, profit, and leverage, if any, may be attributed, with a high level of confidence, to the corporate policy of taking up the ETI-which, effectively, affords the participating firm an abundance of free labour, reduces costs, and boosts operating efficiency, thus enhancing balance sheets and the firm's fundamentals.

\section{$5 \quad$ Data analysis}

\subsection{Sample selection}

The data spans from 2011 to 2016. The sample is limited to this time period because 2016 is the most current year in the Company Income Tax (CIT) panel, provided by the South African National Treasury. SARS provides anonymized tax data to quantify the ETI effect. The tax year in South Africa runs from 1 March to 28 February. The present data treatment and management section draws significantly on Ebrahim et al. (2017), which provides extensive details on the data and its many issues, resulting in some inevitable overlap between this section and that paper. ${ }^{7}$ The basic condition to obtain a voucher is that the ETI bearer should be aged between 18 and 29, earning more than the minimum wage and up to R6,000 per month, and should not be employed in the public sector. We implement a number of filters to align valid claims with the policy specifications by identifying cases deemed fraudulent in the ETI component of the data. Panel A of Table 2 highlights the exclusion assumption criteria.

The first four exclusion criteria outlined in Table 2 are identical to those adopted in Ebrahim et al. (2017). The scope of the identification methodology is broadened by deepening the criteria associated with case 5, which identifies and excludes claims exceeding the maximum statutory ETI claimable amount - a function of an individual wage or income threshold. We therefore adopt an 'over-claimed' identification approach, which considers the income threshold, as opposed to the static over-claimed identification approach adopted in Ebrahim et al. (2017). In other words, the extended trigger for fraudulent claims restricts claims within the voucher-bearer's income threshold and evaluates the claimed amount against the associated maximum claimable amount for that threshold. To illustrate, if an individual falls within the R2,001-4,000 income threshold, her maximum claimable amount for the first 12 months may not exceed R12,000. In the event that such a beneficiary's total claims exceed R12,000 for the 2015 tax year, this activates the exclusion criterion. This procedure applies to the various income thresholds.

\footnotetext{
${ }^{7}$ Please refer to Ebrahim et al. (2017) for a detailed discussion on the ETI data.
} 
Table 2: ETI policy criteria

Panel A: First four ETI policy criteria

Case

Over-age

Under-age

Before policy

Public sector

Panel B: Over-claimed

Monthly wage (ZAR)

$0-2,000$

Claimable amount over 12

months

2,001-4,000

Claimable amount over 12

months

4,001-6,000

Claimable amount over 12

months
Policy specification

ETI claims for individuals older than 29 at the start of their work period

ETI claims for individuals younger than 18 at the start of their work period

ETI claims for individuals whose work period began before 1 October 2013

ETI claims for individuals employed in the public sector

\author{
ETI claimable for second 12 months \\ (ZAR) \\ $25 \%$ of monthly wage \\ $12 \times 0.25$ (monthly wage) \\ 500 \\ 6,000 \\ $1,000-0.25$ (monthly \\ wage $-4,000)$ \\ $12 \times(1,000-0.25$ [monthly \\ wage $-4,000])$
}

Notes: The table presents the criteria used in identifying fraudulent and illegitimate claims. Panel A highlights the first four ETI policy criteria. Panel B highlights, by income threshold, the framework used to clean those claims that exceed their maximum legal ETI claimable amount.

Source: Authors' construction based on IRP5 data.

The procedure outlined in Panel B of Table 2 applies for the years since 2014, during which ETI ran only for the first two months. To obtain the maximum claimable amounts per income threshold for the 2014 tax year, the claimable ETI is multiplied by 2 instead of 12. Thus, an individual falling within the R2,001-4,000 income threshold could only obtain the maximum benefit of R2,000. This procedure broadens the over-claimed aspect of the ETI firm's selection. Also, another subsample is created by setting the ETI claimable amount to 0 for ineligible individuals. Eligible beneficiaries with over-claims are restricted to the statutory ETI amount in line with the beneficiary income threshold. Further, the database provides details on beneficiaries' gender, age, income, etc. Ebrahim et al. (2017) fear that using the single-threshold approach of setting all ETI claim amounts exceeding the maximum claimable amount per year of R12,000 equal to R12,000 across all income thresholds may result in a loss of some ETI information with regard to over-claims falling in the other two income brackets. Therefore, we adopt a multi-income threshold approach allowing us to capture over-claimed cases. ${ }^{8}$

\footnotetext{
${ }^{8}$ With the ETI claimable amount halved in the second year over the course of an individual's claimable benefits, we track voucher claimants, at the individual level, throughout the 24 -month period. Nevertheless, the data did not reveal continuing claims by the same individuals or voucher-bearers beyond 12 months. This implies that the same firm may claim the voucher over the years, but not for the same individuals. This is an unexpected scenario, which may occur owing either to drop-outs or to the extra wage burden being too steep for the firm to continue with the same individual, while younger and more energetic voucher-bearers enter the market at a cheaper rate or higher claimable wage subsidy (up to $50 \%$ in lieu of $25 \%$ of the new hire's salary). Dismissing the old voucher-bearer may be optimal for the hiring firm, thus strengthening its bottom line. Although this does not affect the treatment status of ETI firms, it is more relevant to the ETI intensity tests, which produce results consistent with other inquiries in this study. In the end, this issue is beyond the scope of this study, and may be taken up in future research, namely on the employment side of the policy.
} 
After applying all of the necessary filters, from over 2 million firm-year observations we delete about three-quarters, leading to a final sample of 588,392 firm-year observations, using the 2011 tax year as the pre-ETI reference year. Matching on individual firms' TAXREFNO, we then apply the propensity-score matching technique to this subset of data, which yields a total of 28,082 treated firms and 193,502 treated firm-year observations, of which 140,178 were pre-ETI and 53,324 were post-ETI. ${ }^{9}$ The descriptive statistics for the full sample show that ETI firms present significant differences relative to their non-ETI peers for all of the firm's attributes. Using Equation (1), we derive the propensity scores and successfully matched firms.

Table 3 presents the descriptive statistics for both the full and the matched samples. The statistics show that, on average, firms in this full sample are significantly smaller than ETI firms but comparable in magnitude to non-ETI firms. The size differential between ETI and non-ETI firms disappears after matching. The average firm in the full sample had significantly higher Tobin's Q than the average firm in the ETI group. It is worth noting that ETI firms had higher pre-matching employment levels than those in the full sample and in the non-ETI cohort, indicating that the typical ETI firm may be highly labour-intensive. The firms differ at every level in the pre-matching stage. Virtually all of the differences, but for DIVIDENDS, have been eliminated by the matching process. Admittedly, dividends may reflect a corporate policy of regular dividend pay-outs-a managerial culture that takes time to change absent some material shocks to the firm's finances. Overall, the propensity-score model seems to be successful in forming a balanced sample of ETI and non-ETI firms, as all the control variables in the propensity-score matched sample are insignificantly different at conventional statistical levels between the treatment and control groups.

Table 3: Descriptive statistics

\begin{tabular}{|c|c|c|c|c|c|c|c|}
\hline & \multicolumn{4}{|c|}{ Full sample } & \multicolumn{3}{|c|}{ Propensity-score matched sample } \\
\hline & All obs. & $\begin{array}{r}\text { ETI } \\
\text { firms }\end{array}$ & Non-ETI firms & Means diff. (t-stat) & ETI firms & Non-ETI firms & Means diff (t-stat) \\
\hline Tobin's Q & 0.50 & 0.46 & 0.55 & -13.34 & 0.39 & 0.39 & 0.31 \\
\hline SIZE & 14.86 & 15.86 & 14.72 & 79.82 & 16.06 & 16.05 & 0.24 \\
\hline DIVIDENDS & 0.39 & 0.45 & 0.71 & -77.53 & 0.40 & 0.39 & $2.6^{* *}$ \\
\hline CASHFLOWS & -1.76 & -1.83 & -1.75 & 23.00 & -1.83 & -1.84 & 0.26 \\
\hline EMPLOYMENT & 2.22 & 3.39 & 2.12 & 38.00 & 3.48 & 3.49 & 0.30 \\
\hline
\end{tabular}

Note: ** indicates significant at the $5 \%$ level.

Source: Authors' construction based on IRP5 data.

\subsection{Endogeneity issues and selection bias}

We set out to estimate the counterfactual paths for firms' outcomes using the selected firm-level outcomes as if the treated firms did not experience the ETI treatment. As firms randomly selfselect into the programme, the distribution of programme and non-programme firms minimizes selection bias problems to a large extent. Using PSM, many issues, including selection bias, are resolved, in part, by finding a suitable group of firms which would display similar secular trends in the outcome variables of interest and would present similar secular behaviour absent the ETI

\footnotetext{
${ }^{9}$ Of the 140,178 non-claimants, 25,141, 56,534, and 58,503, were in 2014, 2015, and 2016 respectively. On the other hand, the 53,324 ETI firms were made up of 9,301, 22,329, and 21,694 firms in 2014, 2015, and 2016 respectively.
} 
policy. With observational series before and after the programme for the sampled firms, the effect of the policy can be reasonably evaluated with significantly minimized confounding effects.

Although PSM is a data-driven technique, guaranteeing that the treated firms are observationally comparable with the control firms, considering our involvement in cleaning the ETI data leading to the final sample selection, we must not completely reject the possibility of some level of selection bias legacy. Still, the scope of the panel data set; the statistically significant differences between ETI and non-ETI firms in pre-matching stage; our ability to successfully match on pretreatment characteristics; the statistically insignificant differences between the two groups of firms in post-matching; and the tests for bias reduction in the covariates-ranging from 88.9 to 99.6 per cent-boost our confidence in the selection process and the ensuing post-matching inferences. We employ fixed effects regressions to control for any further differences between the treatment and control groups. The fixed effects approach controls for industry-level effects, yearly fixed effects, and firm-level effects. By adopting this method we seek to better identify the attributable effect of the ETI voucher on the considered firm-level outcomes, and to minimize confounding biases.

\section{Results}

Subsequent to successfully matching ETI and non-ETI firms based on their propensity score, the DiD technique was employed to assess the effect of the ETI on firms. We investigate whether programme firms expand-i.e. increase investment purchases in fixed assets, become more profitable, and have easier access to finance - as a result of taking up the ETI. We pool ETI and non-ETI firms and employ a logistic regression to estimate the probability that a firm will take up the employment voucher based upon observed firm attributes. These firm attributes-SIZE, Tobin's Q, CURNT, CASH, ROA, and LEVERAGE—are significant determinants of a firm taking of the vouchers. The main hypothesis of the paper is that those firms that took up the employment voucher experienced financial and economic gains relative to their non-ETI peers. To test this hypothesis, we apply simple $\mathrm{DiD}$, conditional $\mathrm{DiD}$, triple $\mathrm{DiD}$, and quantile regressions, using robust OLS and fixed effects regressions.

\subsection{Effects of the ETI on firms' growth}

Table 4 displays the results from the DiD estimation using firm growth as the dependent variable. Columns 1-3 provide the coefficients for the full sample. In terms of differences in means between firms claiming the ETI and non-ETI claimants, we note that the coefficients for the average ETIclaiming firm is a healthy $0.056(\mathrm{p}<0.01)$ on firms' growth for the full sample. This suggests that claiming the ETI yields a 5.6 per cent increase in a firm's fixed-to-total-assets ratio. A similar impact is observed using the matched sample, which yields a coefficient estimate of 0.048 $(\mathrm{p}<0.05)$. Our finding regarding firms' expansion as a consequence of ETI take-up is economically and statistically meaningful. Dehejia (2005), Dehejia and Wahba (2002), and Lawrence et al. (2011) concur that differences in means between treatment and control groups are adequate enough to estimate the treatment effects. However, following Lawrence et al. (2011), we employ a multivariate technique to account for remaining characteristic imbalances between ETI and non-ETI firms. 
Table 4: DiD regressions on the effects of the ETI on firms' growth

Full sample

\begin{tabular}{|c|c|c|c|c|c|c|}
\hline & OLS & OLS & FE & OLS & OLS & FE \\
\hline \multirow[t]{2}{*}{ ETI } & $0.0560^{* * *}$ & 0.0275 & 0.0451 & $0.0481^{* *}$ & 0.0150 & 0.0434 \\
\hline & $(0.0197)$ & $(0.0366)$ & $(0.0407)$ & $(0.0208)$ & $(0.0362)$ & $(0.0409)$ \\
\hline \multirow[t]{2}{*}{ Tobin's Q } & & $0.382^{\star \star \star}$ & $0.152^{* \star \star}$ & & $0.472^{\star \star \star}$ & $0.166^{* * *}$ \\
\hline & & $(0.0122)$ & $(0.0326)$ & & $(0.0201)$ & $(0.0358)$ \\
\hline \multirow[t]{2}{*}{ CASHFLOW } & & $-0.0762^{* * *}$ & $-0.217^{\star \star *}$ & & $-0.0725^{\star * *}$ & $-0.216^{\star * *}$ \\
\hline & & $(0.00402)$ & $(0.0142)$ & & $(0.00467)$ & $(0.0149)$ \\
\hline \multirow[t]{2}{*}{ CASH HOLDING } & & $-0.0447^{\star \star \star}$ & $-0.193^{\star \star \star}$ & & -0.0348 & $-0.193^{\star \star *}$ \\
\hline & & $(0.0115)$ & $(0.0593)$ & & $(0.0293)$ & $(0.0631)$ \\
\hline \multirow[t]{2}{*}{ GDP } & & $1.647^{\star \star *}$ & & & $0.992^{\star \star \star}$ & \\
\hline & & $(0.322)$ & & & $(0.376)$ & \\
\hline Observations & 247,665 & 58,258 & 30,162 & 170,274 & 46,929 & 26,978 \\
\hline Fixed effects & No & No & Yes & No & No & Yes \\
\hline Year effects & Yes & Yes & Yes & Yes & Yes & Yes \\
\hline R-squared & 0.005 & 0.041 & 0.763 & 0.006 & 0.041 & 0.762 \\
\hline
\end{tabular}

Notes: Specifications 1-3 show the estimates for the full sample. Specifications 4-6 exhibit the DiD estimates for the PSM sample. Described in Table 1, the control variables include Tobin's Q, CASHFLOW, CASH HOLDING, and log GDP. Robust standard errors in parentheses; ${ }^{* *},{ }^{* *}$, and * refer to $1 \%, 5 \%$, and $10 \%$ levels of significance, respectively.

Source: Authors' construction based on IRP5 data.

We run DiD regressions accounting for firm characteristics that may influence firm growth. Column 2 (4) presents the OLS results and Column 3 (6) the fixed effects results for the full sample (matched sample). Results for both the full and matched samples show that firm growth is positively influenced by the wage subsidy. Multivariate estimates for the full and the propensityscore matched samples are positive, yet statistically insignificant. The ETI effect is muted using the conditioning set of variables. Overall, the results corroborate Saez et al. (2019) and Zwick and Mahon (2017). In particular, Saez et al. (2019), studying the firm-level effects of an employment tax rate cut for workers aged 26 or younger in Sweden, provide graphical evidence showing that firms with higher proportions of targeted workers expand after the reform in terms of capital, sales, value added, and profits. However, the results are at odds with Anderson and Meyer (1997), Bennmarker, et al. (2009), Kaunitz and Egebark, (2019), Korkeamäki and Uusitalo (2009), and Murphy (2007), who find no consensus on the effects on firms of employment tax cuts. Most importantly, Zwick and Mahon (2017) provide estimates showing that US temporary tax incentives for investment substantially raised investments by as much as 10.4 per cent between 2001 and 2004 and roughly 17 per cent between 2008 and 2010, with an effect that was singularly pronounced at small firms.

\subsection{Effects of the ETI on firms' profitability}

Table 5 presents the results for DiD estimations of the effect of the ETI on firms' profits. OLS results for both the full and the matched samples are similar in magnitude to those for the simple DiD model. Likewise, the OLS coefficient for the conditional DiD in the propensity-score matched sample is $0.0569(\mathrm{p}<0.01)$. This result implies that the average ETI-claiming firm witnessed an increase in profitability of about 5.7 per cent. The estimate suggests that ETI claimants are able to utilize increased subsidized employment to enhance profitability. 
Table 5: DiD regressions on the effects of the ETI on firms' profits

\begin{tabular}{|c|c|c|c|c|c|c|}
\hline & \multicolumn{3}{|c|}{ Full sample } & \multicolumn{3}{|c|}{ Propensity-score matched sample } \\
\hline & OLS & OLS & FE & OLS & OLS & FE \\
\hline ETI & $\begin{array}{l}0.106^{* * *} \\
(0.0131)\end{array}$ & $\begin{array}{r}0.0516^{\star * \star} \\
(0.0134)\end{array}$ & $\begin{array}{l}0.0278^{* * *} \\
(0.00993)\end{array}$ & $\begin{array}{l}0.102^{* * *} \\
(0.0146)\end{array}$ & $\begin{array}{r}0.0569^{* * *} \\
(0.0147)\end{array}$ & $\begin{array}{r}0.0316^{\star \star *} \\
(0.01)\end{array}$ \\
\hline LEVERAGE & & $\begin{array}{r}-0.0571^{* * *} \\
(0.00175)\end{array}$ & $\begin{array}{r}-7.23 E-05 \\
(0.00325)\end{array}$ & & $\begin{array}{r}-0.0523^{\star \star \star} \\
(0.00228)\end{array}$ & $\begin{array}{l}(0.00065) \\
(0.00326)\end{array}$ \\
\hline SIZE & & $\begin{array}{l}-0.333^{\star * *} \\
(0.00245)\end{array}$ & $\begin{array}{l}0.603^{\star * *} \\
(0.0221)\end{array}$ & & $\begin{array}{l}-0.323^{\star \star \star} \\
(0.00428)\end{array}$ & $\begin{array}{l}0.609^{\star * *} \\
(0.0251)\end{array}$ \\
\hline EMPLOYMENT & & $\begin{array}{c}0.320^{\star * *} \\
(0.00264)\end{array}$ & $\begin{array}{c}0.195^{\star * *} \\
(0.00898)\end{array}$ & & $\begin{array}{r}0.311^{* * *} \\
(0.00401)\end{array}$ & $\begin{array}{l}0.191^{* * *} \\
(0.0099)\end{array}$ \\
\hline CASHFLOW & & $\begin{array}{l}0.0743^{* * *} \\
(0.00267)\end{array}$ & $\begin{array}{c}0.125^{\star * *} \\
(0.00506)\end{array}$ & & $\begin{array}{l}0.0621^{\star * \star} \\
(0.00554)\end{array}$ & $\begin{array}{l}0.127^{\text {** }} \\
(0.0057)\end{array}$ \\
\hline Observations & 246,082 & 148,254 & 126,591 & 168,127 & 116,482 & 107,050 \\
\hline Fixed effects & No & No & Yes & No & No & Yes \\
\hline Year effects & Yes & Yes & Yes & Yes & Yes & Yes \\
\hline R-squared & 0.014 & 0.235 & 0.852 & 0.012 & 0.214 & 0.851 \\
\hline
\end{tabular}

Notes: Specifications 1-3 show the estimates of the effects using the full sample. Specifications 4-6 exhibit the DiD estimates using the PSM sample. Described in Table 1, the control variables include LEVERAGE, SIZE, CASHFLOW, and EMPLOYMENT. Robust standard errors in parentheses; ${ }^{* * *}$, ${ }^{* *}$, and ${ }^{*}$ refer to $1 \%, 5 \%$, and $10 \%$ levels of significance, respectively

Source: Authors' construction based on IRP5 data.

The estimates for the average programme firm's profitability corroborate those reported by Saez et al. (2019) and Zwick and Mahon (2017). The effect may operate through reduced average costs, which may lead to an output effect-by extension, a price and income effect. Lower production costs are associated with greater aggregate demand as prices slump. This in turn should strengthen the firm's balance sheet, as programme participation is associated with greater profit realizationsdriven, perhaps, by greater operating results or firm efficiency. Balasubramanyan and Mohan (2010) and Dwyer (2001), among others, document a positive relationship between productivity and firm value.

With greater investment and profit levels at programme firms, it appears that ETI performs a legitimate economic function by enhancing the firm's value. This may have broader economic ramifications. The results are consistent with the hypothesis that labour is a key factor driving production and firm value. Labour tends to significantly affect operating costs and profitability in labour-intensive industries. If capital-intensive firms increase their ETI utilization rate in pursuit of windfalls, they may operate a decreasing-returns-to-scale technology, thus hampering productivity and growth in the long haul. By altering average costs of production for programme firms, and as a corollary to their competitiveness, the programme effect may work through other channels through its interactions with other key variables, e.g., firms' growth, sales, and operating income. Nonetheless, these effects ultimately depend on individual firms' characteristics. Therefore, the full effect of the programme on firms is beyond the scope of this study.

\subsection{Effects of ETI on firms' leverage}

Our findings show that ETI firms increase leverage significantly. The OLS DiD estimates, as shown in Columns 1 and 4 of Table 6, show a positive and significant effect of ETI on firms' access to external finance. In particular, the DiD estimate is $0.054(\mathrm{p}<0.01)$ for the full sample and $0.066(p<0.01)$ for the propensity-score matched sample. With respect to the effect of ease of access to finance-indebtedness-the literature is far from settled. The net benefits of debt 
financing rise for companies with low debt, but at a certain point debt weighs down on profits and increases a firm's vulnerability to financial distress. Several scholars concur that with heightened default risks, expanding corporate leverage may depress investments and induce severe slowdowns, thereby propagating adverse shocks in the economy (Bernanke et al. 1999; Coricelli et al. 2012; Kiyotaki and Moore 1997; Marcelin and Mathur 2014, 2015; Mathur and Marcelin 2014, 2015). Coricelli et al. (2012) discuss the point at which corporate indebtedness becomes a cause for concern.

Table 6: DiD regressions on the effects of the ETI on firms' leverage

\begin{tabular}{|c|c|c|c|c|c|c|}
\hline & & Full sample & & Propensit & -score match & sample \\
\hline & OLS & OSL & FE & OLS & OLS & FE \\
\hline ETI & $0.0541^{\star \star \star}$ & 0.000299 & $0.0184^{\star *}$ & $0.0663^{\star \star *}$ & 0.0192 & $0.0171^{* *}$ \\
\hline & $(0.0203)$ & $(0.0129)$ & $(0.00836)$ & $(0.0221)$ & $(0.0134)$ & $(0.00841)$ \\
\hline SIZE & & $-0.702^{* * *}$ & $-0.714^{\star * *}$ & & $-0.698^{\star \star \star}$ & $-0.707^{\star \star \star}$ \\
\hline & & $(0.00295)$ & $(0.00972)$ & & $(0.00380)$ & $(0.0106)$ \\
\hline Tobin's Q & & $-0.0571^{\star * \star}$ & $-0.0853^{\star * *}$ & & $-0.0916^{\star \star \star}$ & $-0.0822^{\star \star \star}$ \\
\hline & & $(0.00474)$ & $(0.00799)$ & & $(0.00754)$ & $(0.00956)$ \\
\hline FINCONSTRAINTS & & $-0.0124^{\star \star *}$ & $-0.0157^{\star \star *}$ & & $-0.0112^{\star \star *}$ & $-0.0158^{\star \star \star}$ \\
\hline & & $(0.00217)$ & $(0.00273)$ & & $(0.00262)$ & $(0.00286)$ \\
\hline DIVIDENDS & & $0.850^{\star \star \star}$ & $0.0950^{\star * *}$ & & $0.838^{\star \star \star}$ & $0.0974^{\star \star \star}$ \\
\hline & & $(0.00722)$ & $(0.0103)$ & & $(0.00838)$ & (0.0108) \\
\hline PROFITS & & $6.40 \mathrm{e}-06^{* \star *}$ & $2.49 \mathrm{e}-06^{\star *}$ & & $6.39 \mathrm{e}-06^{\star \star *}$ & $2.41 \mathrm{e}-06^{\star *}$ \\
\hline & & $(9.55 \mathrm{e}-07)$ & $(1.27 \mathrm{e}-06)$ & & $(1.41 \mathrm{e}-06)$ & $(1.21 \mathrm{e}-06)$ \\
\hline Observations & 247,566 & 195,962 & 177,281 & 186,437 & 154,467 & 148,259 \\
\hline Fixed effects & No & No & Yes & No & No & Yes \\
\hline Years effects & Yes & Yes & Yes & Yes & Yes & Yes \\
\hline R-squared & 0.071 & 0.648 & 0.934 & 0.078 & 0.648 & 0.934 \\
\hline
\end{tabular}

Notes: Specifications 1-3 show the estimates of the effects using the full sample. Specifications 4-6 exhibit the estimates for the PSM sample. Described in Table 1, the control variables include SIZE, Tobin's $Q$,

FINCONSTRAINTS, DIVIDENDS, and PROFITS. Robust standard errors in parentheses; ${ }^{* *},{ }^{* *}$, and * refer to $1 \%, 5 \%$, and $10 \%$ levels of significance, respectively.

Source: Authors' construction based on IRP5 data.

Together, the results imply that firms that took up the employment voucher were able to increase investment as well as to adopt more aggressive financing policies. By increasing leverage, ETI may have eased access to credit, allowing greater investment purchases and profitability. The results suggest that the labour subsidy policy had meaningful impact on firms' valuation, financing, and investment decisions. The ease of access to credit is indicative of financial development, and is of great relevance for countries seeking to develop their financial market to allow firms to tap into investible resources to finance growth. Nonetheless, leveraging the firm may induce negative effects in the long run. At some point, the adverse effects of heightened leverage overtake its benefits, as debt needs to be serviced and debt overhang may cripple the firm's ability to purchase productive investment.

The fact that ETI firms generate greater profits may be an indicator of improved solvency allowing firms to resolve some frictions related to credit markets, since they are likely to exhibit stronger liquidity positions. Higher profitability is associated with greater cash flows, which may ease access to external credit by lowering the costs of capital. Improvements in GROW'TH, PROFITS, and LEVERAGE should not be analysed in isolation from one another. If the ETI leads to enhanced profits, it may well unlock credit. Enhanced internal funds allow firms to avoid many of the hassles of financial markets owing to their stronger financial position and augmented net worth. On a related note, it may be argued that by relaxing credit constraints, among the effects of the policy 
are a minimization of participating firms' cost of capital and an alleviation of fiscal burdens. Desai et al. (2004), Faccio and Xu (2015), and Fan et al. (2012) document a significant link between taxes and firms' capital structure decisions. It is possible that ETI claimants use their capital structure to create value, in part, owing to the lower cost of capital, the higher net worth, and the differential tax treatment. Small firms, informationally challenged, can use their cash flows as a lever to defray costs to external finance, stabilize earnings volatility, and acquire valuable investments.

\subsection{ETI effects on firms' growth, profitability, and leverage: Other tests}

We extend the DiD framework to triple $\mathrm{DiD}$ to examine whether the ETI effect varies by intensity of ETI utilization, firm size, and degree of financial constraints. Triple DiD allows for more interactions to capture firms' response to the ETI policy. Econometrically, we capture the effect as it varies depending on the scope of treatment and SIZE through time. We recoup time-varying changes for ETI firms, controlling for time-invariant firm characteristics. We capture differences in firms' growth attributable to the ETI. Further, we employ quantile regressions to produce robust and localized estimates. We repeat the test for firms' degree of financial constraints using firms' profitability and debt capacity as dependent variables. Table 7 exhibits two sets of results: Columns 1 and 4 show the results by intensity of ETI utilization; Columns 2-3 and 5-6 show the results for small firms, i.e. those in the lowest decile of ETI distribution.

Table 7: Triple-DiD regressions on the effects of the ETI on firms' growth

\begin{tabular}{|c|c|c|c|c|c|c|}
\hline & \multicolumn{3}{|c|}{ Full sample } & \multicolumn{3}{|c|}{ Propensity-score matched sample } \\
\hline & OLS & OLS & FE & OLS & OLS & FE \\
\hline \multirow[t]{2}{*}{ ETI } & $0.102^{* *}$ & 0.0442 & & $0.0994^{* *}$ & 0.0153 & \\
\hline & $(0.0431)$ & $(0.0493)$ & & $(0.0476)$ & $(0.0502)$ & \\
\hline \multirow[t]{2}{*}{ Tobin's Q } & & $0.502^{* * *}$ & $0.152^{\star \star \star}$ & & $0.575^{\star \star *}$ & $0.166^{* * *}$ \\
\hline & & $(0.0154)$ & $(0.0326)$ & & $(0.0193)$ & $(0.0358)$ \\
\hline \multirow[t]{2}{*}{ SIZE } & & $0.0988^{* * *}$ & & & $0.0710^{* * *}$ & \\
\hline & & $(0.00883)$ & & & $(0.00953)$ & \\
\hline \multirow[t]{2}{*}{ EMPLOYMENT } & & $0.278^{* * \star}$ & & & $0.288^{* * *}$ & \\
\hline & & $(0.00967)$ & & & $(0.0106)$ & \\
\hline \multirow[t]{2}{*}{ CASHFLOW } & & $0.254^{\star \star \star}$ & $-0.193^{\star \star \star}$ & & $0.251^{\star \star *}$ & $-0.193^{\star \star *}$ \\
\hline & & $(0.00975)$ & $(0.0594)$ & & $(0.0107)$ & $(0.0631)$ \\
\hline \multirow[t]{2}{*}{ DIVIDENDS } & & $0.412^{* \star \star}$ & & & $0.364^{\star * *}$ & \\
\hline & & $(0.0268)$ & & & $(0.0285)$ & \\
\hline \multirow[t]{2}{*}{ ETI_INTENSITY } & & & -0.0416 & & & -0.0431 \\
\hline & & & $(0.0513)$ & & & $(0.0553)$ \\
\hline \multirow[t]{2}{*}{ CASH_HOLDING } & & & $-0.217^{\star \star \star}$ & & & $-0.216^{\star \star \star}$ \\
\hline & & & $(0.0142)$ & & & $(0.0149)$ \\
\hline Observations & 247,665 & 171,413 & 30,162 & 170,274 & 140,693 & 26,978 \\
\hline Fixed effects & No & No & Yes & No & No & Yes \\
\hline Year effects & Yes & Yes & Yes & Yes & Yes & Yes \\
\hline R-squared & $\mathrm{n} / \mathrm{a}$ & $\mathrm{n} / \mathrm{a}$ & 0.763 & $\mathrm{n} / \mathrm{a}$ & $n / a$ & 0.762 \\
\hline
\end{tabular}

Notes: Specifications 1-3 show the effects using the full sample. Specifications 4-6 exhibit the estimates for the PSM sample. OLS are quantile-based regressions. The control variables, described in Table 1, include SIZE, Tobin's Q, EMPLOYMENT, DIVIDENDS, CASH_HOLDING, and ETI_INTENSITY. In specifications 3 and 6, ETI_INTENSITY is the triple interaction between ETI_FIRM, POST-ETI, and our measure of ETI intensity. ETI_ INTENSITY is our fixed effects triple-DiD estimator, and the OLS results follow a quantile regression approach, conditional on the ETI intensity distribution. To capture the ETI effect on the growth of small firms, the quantile OLS were performed at the lowest decile of the ETI distribution. Robust standard errors in parentheses; ${ }^{* *},{ }^{* *}$, and * refer to $1 \%, 5 \%$, and $10 \%$ levels of significance, respectively.

Source: Authors' construction based on IRP5 data. 
Columns 1 and 3 of Table 7 show that, in general, for small firms in the first decile of ETI distribution, expansion as a result of ETI utilization is particularly strong and statistically significant. We observe a significant increase in ETI firms' growth, with a coefficient estimate of 0.0994 ( $p<0.05$ ), suggesting that small firms expand by about 10 per cent in terms of growth in capital goods acquisitions. Though smaller in magnitude, the estimates compare well with those reported by Zwick and Mahon (2017). However, Ebrahim et al. (2017) report that larger and older firms have a higher ETI take-up rate. The conditional triple-DiD estimates are statistically insignificant for large ETI claimants, suggesting a slow response in investment among larger ETI firms. This suggests perhaps that large firms need more time for investment upgrades, and that resources generated as a result of take-up of the voucher have not altered their capital budgeting plans. All control variables-SIZE, Tobin's Q, CASHFLOW, DIVIDENDS, etc.- display signs consistent with financial theory and are significant at the 1 per cent level.

Table 8 presents the triple-DiD estimates of the ETI effect on firms' profitability. Columns 1 and 4 show the OLS estimates varying by firm size. The coefficient on the triple interaction is statistically insignificant for both the full and the matched sample. However, relative to their larger ETI-recipient counterparts, smaller firms show a significant increase in profitability. Quantile regression results show a growth in profitability of as much as 11 per cent at small and creditconstrained ETI firms located in the first decile.

Table 8: Triple-DiD regressions on the effects of the ETI on firms' profits

\begin{tabular}{|c|c|c|c|c|c|c|}
\hline & & Full sample & & Propensi & score match & sample \\
\hline & OLS & OLS & FE & OLS & OLS & FE \\
\hline ETI & $0.146^{* * *}$ & $0.114^{\star \star \star}$ & & $0.115^{\star \star \star}$ & $0.110^{\star * *}$ & \\
\hline & $(0.0245)$ & $(0.0200)$ & & $(0.0245)$ & $(0.0205)$ & \\
\hline ETI_INTENSITY & & & -0.0110 & & & -0.0174 \\
\hline & & & $(0.0133)$ & & & $(0.0145)$ \\
\hline LEVERAGE & & $-0.0686^{\star \star *}$ & $-8.29 e-05$ & & $-0.0512^{\star \star \star}$ & -0.000660 \\
\hline & & $(0.00262)$ & $(0.00325)$ & & $(0.00290)$ & $(0.00326)$ \\
\hline SIZE & & $-0.395^{\star \star \star}$ & $0.603^{\star \star \star}$ & & $-0.400^{* * *}$ & $0.609^{\star \star \star}$ \\
\hline & & $(0.00367)$ & $(0.0221)$ & & $(0.00419)$ & $(0.0251)$ \\
\hline EMPLOYMENT & & $0.416^{\star \star *}$ & $0.196^{* \star *}$ & & $0.402^{\star \star *}$ & $0.192^{\star \star *}$ \\
\hline & & $(0.00396)$ & $(0.00898)$ & & $(0.00439)$ & $(0.00991)$ \\
\hline CASHFLOW & & $0.147^{\star \star \star}$ & $0.125^{\star \star \star}$ & & $0.156^{\star \star \star}$ & $0.127^{\star \star \star}$ \\
\hline & & $(0.00401)$ & $(0.00506)$ & & $(0.00453)$ & $(0.00568)$ \\
\hline Observations & 246,082 & 148,254 & 126,591 & 168,127 & 116,482 & 107,050 \\
\hline Fixed effects & No & No & Yes & No & No & Yes \\
\hline Year effects & Yes & Yes & Yes & Yes & Yes & Yes \\
\hline R-squared & $n / a$ & $\mathrm{n} / \mathrm{a}$ & 0.852 & $\mathrm{n} / \mathrm{a}$ & $\mathrm{n} / \mathrm{a}$ & 0.851 \\
\hline
\end{tabular}

Notes: Specifications 1-3 show the effects using the full sample. Specifications 4-6 exhibit the estimates for the PSM sample. OLS are quantile-based regressions. The control variables, described in Table 1, include SIZE, LEVERAGE, EMPLOYMENT, CASHFLOW, and ETI_INTENSITY. In specifications 3 and 6, ETI_INTENSITY is the triple interaction between ETI_FIRM, POST-ETI, and our measure of ETI intensity. ETI_ INTENSITY is our fixed effects triple-DiD estimator, and the OLS results follow a quantile regression approach, conditional on the ETI intensity distribution. To capture the ETI effect on the profitability of small firms, the quantile OLS were performed at the lowest decile of the ETI distribution. Robust standard errors in parentheses; ${ }^{* *}$, ${ }^{* *}$, and * refer to $1 \%, 5 \%$, and $10 \%$ levels of significance, respectively.

Source: Authors' construction based on IRP5 data.

While the primary purpose of the ETI policy is to spur employment of eligible workers, by reducing firms' average costs the programme may stimulate the economy through positive spillovers among firms and across sectors, resulting in a complex linkage between the policy and firms. With the ever-increasing importance of small firms in the economy, these estimates are of 
great relevance for policymakers. Bishop and Montgomery (1993) highlight an output channel when reduced costs associated with subsidized labour lead to price reduction and increased demand. This effect may help to explain increased profitability at programme firms.

The association between programme take-up and greater profit realization suggests improvements in ETI firms' operating efficiency. Among others, Balasubramanyan and Mohan (2010) and Dwyer (2001) document a positive relationship between productivity and firm value. The estimates are robust to controlling for industry and year indicators for both the full and the matched samples. Importantly, as shown in Table 9, for both the full and the matched samples the coefficient on LEVERAGE is positive and significant at the 1 per cent level for small ETI claimants, suggesting that the profitability of ETI firms situated in the first decile of the ETI distribution expands, in the short term, notwithstanding the higher debt burdens. All other coefficients show directional effects consistent with established theories.

Table 9: Triple-DiD regressions on the effects of the ETI on firms' debt capacity

\begin{tabular}{|c|c|c|c|c|c|c|}
\hline & \multirow[b]{2}{*}{ OLS } & \multicolumn{2}{|r|}{ Full sample } & \multicolumn{3}{|c|}{ Propensity-score matched sample } \\
\hline & & OLS & $\mathrm{FE}$ & OLS & OLS & $\mathrm{FE}$ \\
\hline \multirow[t]{2}{*}{ ETI } & 0.0198 & $0.0470^{*}$ & & 0.0482 & $0.0609^{\star \star}$ & \\
\hline & $(0.0385)$ & $(0.0250)$ & & $(0.0412)$ & $(0.0263)$ & \\
\hline ETI_INTENSITY & & & $\begin{array}{r}-0.0281^{* *} \\
(0.0116)\end{array}$ & & & $\begin{array}{r}-0.0293^{\star \star} \\
(0.0124)\end{array}$ \\
\hline \multirow[t]{2}{*}{ SIZE } & & $-0.747^{\star * *}$ & $-0.714^{* \star *}$ & & $-0.749^{\star * *}$ & $-0.707^{\star \star \star}$ \\
\hline & & $(0.00571)$ & $(0.00972)$ & & $(0.00639)$ & $(0.0106)$ \\
\hline \multirow[t]{2}{*}{ Tobin's Q } & & $-0.199^{* \star *}$ & $-0.0853^{* * *}$ & & $-0.262^{\star \star \star}$ & $-0.0822^{* \star *}$ \\
\hline & & $(0.00917)$ & $(0.00799)$ & & $(0.0120)$ & $(0.00956)$ \\
\hline \multirow[t]{2}{*}{ FINCONSTRAINTS } & & $0.0224^{* * *}$ & $-0.0157^{\star * *}$ & & $0.0257^{* * *}$ & $-0.0159^{\star * \star}$ \\
\hline & & $(0.00421)$ & $(0.00273)$ & & $(0.00469)$ & $(0.00286)$ \\
\hline \multirow[t]{2}{*}{ DIVIDENDS } & & $1.146^{\star * *}$ & $0.0950^{\star \star *}$ & & $1.129^{\star \star \star}$ & $0.0974^{\star \star \star}$ \\
\hline & & $(0.0140)$ & $(0.0103)$ & & $(0.0153)$ & $(0.0108)$ \\
\hline \multirow[t]{2}{*}{ PROFITS } & & $5.98 \mathrm{e}-06^{\star \star \star}$ & $2.49 \mathrm{e}-06^{\star \star}$ & & $5.98 \mathrm{e}-06^{\star \star \star}$ & $2.41 \mathrm{e}-06^{\star *}$ \\
\hline & & $(1.85 e-06)$ & $(1.27 e-06)$ & & $(1.84 \mathrm{e}-06)$ & $(1.21 \mathrm{e}-06)$ \\
\hline Observations & 247,566 & 195,962 & 177,281 & 186,437 & 154,467 & 148,259 \\
\hline Fixed effects & No & No & Yes & No & No & Yes \\
\hline Year effect & Yes & Yes & Yes & Yes & Yes & Yes \\
\hline R-squared & $\mathrm{n} / \mathrm{a}$ & $\mathrm{n} / \mathrm{a}$ & 0.934 & $\mathrm{n} / \mathrm{a}$ & $\mathrm{n} / \mathrm{a}$ & 0.934 \\
\hline
\end{tabular}

Notes: Specifications 1-3 show the effects using the full sample. Specifications 4-6 exhibit the estimates for the PSM sample. OLS are quantile-based regressions. The control variables, described in Table 1, include SIZE, LEVERAGE, EMPLOYMENT, CASHFLOW, and ETI_INTENSITY. In specifications 3 and 6, ETI_INTENSITY is the triple interaction between ETI_FIRM, POST-ETI, and our measure of ETI intensity. ETI_INTENSITY is our fixed effects triple-DiD estimator, and the OLS results follow a quantile regression approach, conditional on the ETI intensity distribution. To capture the ETI effect on debt capacity of small firms, the quantile OLS were performed at the lowest decile of the ETI distribution. Robust standard errors in parentheses; ${ }^{* \star *}$, ${ }^{* *}$, and * refer to $1 \%, 5 \%$, and $10 \%$ levels of significance, respectively.

Source: Authors' construction based on IRP5 data.

An interesting pattern emerges in Table 9, displaying the triple-DiD results for ETI firms' leverage, measured by the ratio of long-term liabilities to total assets. Unsurprisingly, large firms, presumably financially unconstrained, reduce their debt burden as a result of ETI take-up. Perhaps, instead of acquiring new investments large firms elect to reduce their debt load in the short term. In contrast, smaller firms increase LEVERAGE as a result of ETI take-up. Columns 1 and 4 of Table 9 show an insignificant effect of the ETI for all firms for both the full and the propensity-matched samples. Columns 2 and 5 show that LEVERAGE increases for small ETI firms and declines for large ETI firms for both the full and the matched samples. In fact, the estimate on ETI intensity 
is $-0.0281(\mathrm{p}<0.01)$ for the full sample and $-0.0293(\mathrm{p}<0.05)$ for the propensity-score matched sample. This also implies that large ETI firms witnessed significant financial improvements and rely less on LEVERAGE. Multivariate results for the matched sample also show an increase in LEVERAGE at small ETI firms by 6.1 per cent, significant at the 5 per cent level. Although weaker, we see an increase by 4.7 per cent for ETI firms in the first decile of firms' SIZE distribution, significant at the 10 per cent level. These results are consistent with the liquidity effect theory highlighted in Saez et al. (2019) for small and financially constrained firms.

For a small, financially constrained firm, if ETI take-up improves the bottom line, this is expected to have important ramifications for free cash flows and access to external finance through the cost-of-capital channel. ${ }^{10}$ An informationally challenged firm can use any extra cash flows as levers to defray costs to external finance, stabilize earnings volatility, and purchase invaluable investments. Our results imply that the ETI alleviates small claimants' borrowing constraints, facilitating the substitution of equity for debt through a lower cost of debt financing. Consistent with the pecking order theory, programme firms - at least those in the first decile of the SIZE distribution - have greater access to internal finance, owing to greater profitability. Having access to better internal and/or external finance through debt and equity markets can provide a significant competitive edge for firms (Caglayan and Demir 2014). The pecking order theory implies a shift in capital structure as firms become more profitable, owing to a decline in the cost of a given input factor, as this input becomes abundant. Armenter and Hnatkovska (2011) maintain that an additional monetary unit of internal funds allows a low-net-worth firm to build its net worth faster and escape being financially constrained in the event of a negative shock because equity acts as a form of insurance.

\subsection{Financially constrained firms' responses to the ETI}

In Tables 10,11, and 12, we specifically test for the growth rate, profitability, and debt capacity of financially constrained ETI claimants. Column 1 in Table 10 confirms the strong response of investment to the ETI initiative. In particular, the economic activity of the financially constrained firm rises by 7.43 per cent in the full sample. Using large ETI users and controlling for firms' characteristics yields a muted effect in the multivariate framework-beyond the simple triple-DiD. This puts the results on par with those of Kaunitz and Egebark (2019), who document a negligible effect of the Finnish payroll tax cut on gross investments. Saez et al. (2019) suggest that, theoretically, firms that are particularly constrained in their access to finance (debt or equity) should be particularly responsive to the cash effect of the employment subsidy. The liquidity injection from the ETI represents a differential percentage in total labour cost reduction for participating firms irrespective of their size. Thus, even with noisy outcome variables such as investment acquisitions, large firms may still benefit from the expansionary policy. Admittedly, if the shift in assets falls within the top range of our estimate of 7.43 per cent even for small firms, this should be perceived as a substantial effect of the cash infusion in the economy through the policy enactment.

Fazzari et al. (1988) maintain that cash windfalls have important implications for investment growth, and that internal finance has important cost advantages over external finance-an effect they attribute to firms' limited access to credit. Ceteris paribus, a firm, notwithstanding its size, may favour hiring a young worker at half the cost rather than an older worker presenting the same skill set. Kaplan and Zingales (1995) refute Fazzari et al.'s (1988) notion that investment-cash-flow sensitivity responds to financial constraints. Later, Kaplan and Zingales (1997) concede that

\footnotetext{
${ }^{10}$ See Marcelin and Mathur $(2015,2016)$ and Mathur and Marcelin $(2014,2015)$ for detailed discussions on firms' access to external finance.
} 
financially constrained firms display a higher propensity for lower investment-cash-flow sensitivities than less financially constrained firms.

Table 10: Triple-DiD regressions on the effects of the ETI on financially constrained firms' growth

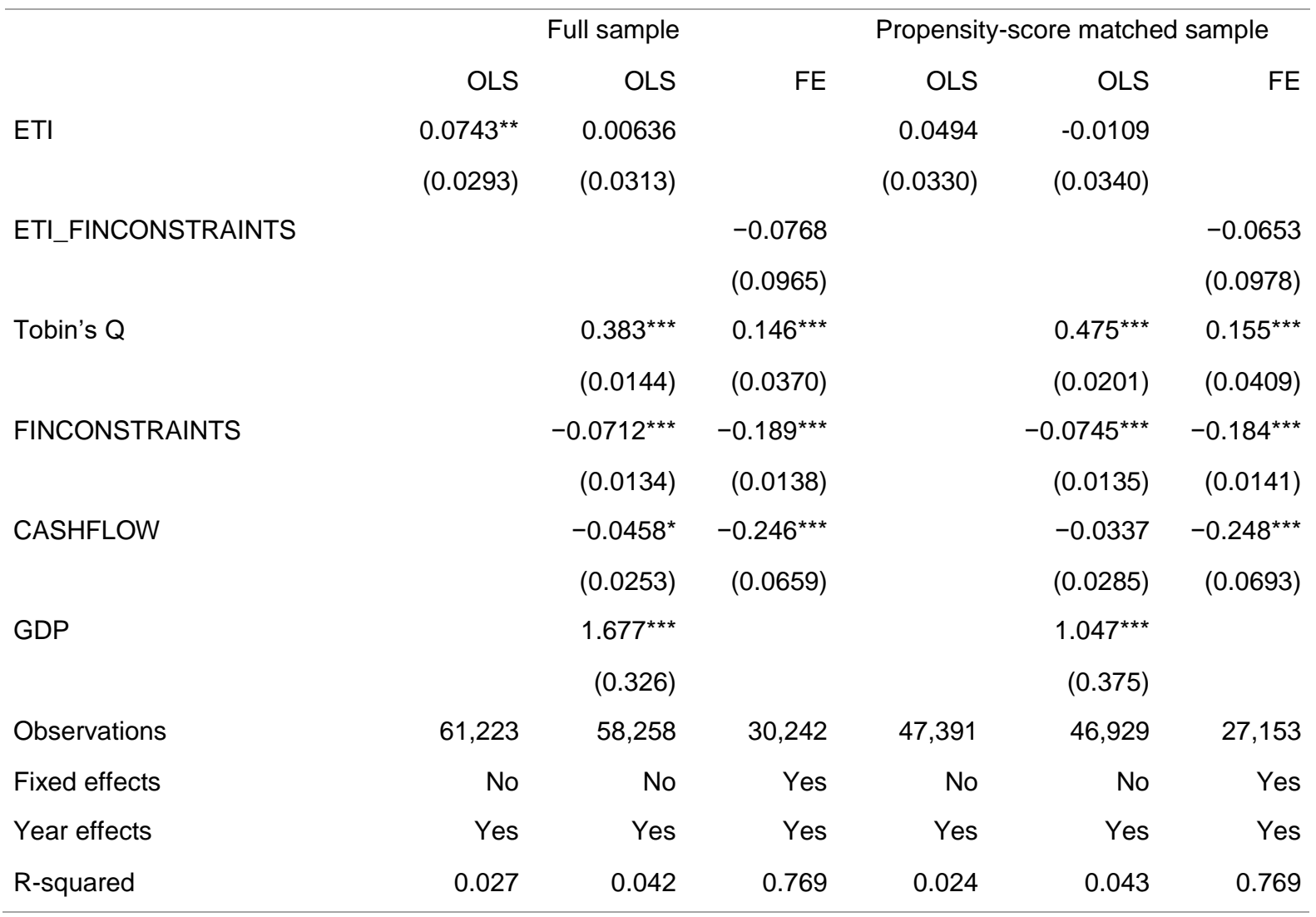

Notes: Specifications 1-3 show the effects using the full sample. Specifications 4-6 exhibit the estimates for the PSM sample. The control variables, described in Table 1, include Tobin's, CASHFLOW, and financial constraints, measured as CASHFLOW/FIXED ASSET, CASHFLOW, and GDP. In specifications 3 and 6,

ETI FINCONSTRAINTS is the triple interaction between ETI FIRM, POST-ETI, and our measure of ETI

intensity. ETI_FINCONSTRAINTS is our fixed effects triple-DiD estimator, and the OLS results follow a quantile regression approach, conditional on the financial constraints distribution. To capture the ETI effect on the growth of financially constrained firms, the quantile OLS were performed at the lowest decile of the FIN_CONSTRAINTS distribution. Robust standard errors in parentheses; ${ }^{* * *},{ }^{* *}$, and * refer to $1 \%, 5 \%$, and $10 \%$ levels of significance, respectively.

Source: Authors' construction based on IRP5 data.

Silva and Carreira (2012) compile the different techniques commonly employed to measure financial constraints. Following Carpenter and Petersen (2002), Fagiolo and Luzzi (2006), and Oliveira and Fortunato (2006), we model financial constraints as firms' cash flows deflated by CAPEX, the indicator for which the growth rate is under investigation. Consistent with standard investment models, we control for Tobin's Q, an indicator of the firm's investment opportunities. Other control variables including SIZE, LEVERAGE, CASH, and GDP, all of which preserve their directionality consistent with theory. In Table 11, we consider the profitability of financially constrained ETI firms using firm size and the ratio of cash flows to firms' gross revenue, consistent with the technique outlined in Silva and Carreira (2012) and implemented by Carpenter and Petersen (2002), Fagiolo and Luzzi (2006), and Oliveira and Fortunato (2006). 
Table 11: Triple-DiD regressions on the effects of the ETI on financially constrained firms' profits

\begin{tabular}{|c|c|c|c|c|c|c|}
\hline & \multicolumn{3}{|c|}{ Full sample } & \multicolumn{3}{|c|}{ Propensity-score matched sample } \\
\hline & OLS & OLS & FE & OLS & OLS & FE \\
\hline \multirow[t]{2}{*}{ ETI } & $0.156^{\star * *}$ & 0.00866 & & $0.141^{* * *}$ & $0.0160^{\star *}$ & \\
\hline & $(0.00727)$ & $(0.00815)$ & & $(0.00906)$ & $(0.00774)$ & \\
\hline \multirow[t]{2}{*}{ ETI_FINCONSTRAINTS } & & $-0.0425^{\star \star \star}$ & -0.000195 & & $-0.0442^{\star \star \star}$ & -0.000705 \\
\hline & & $(0.00394)$ & $(0.00322)$ & & $(0.00351)$ & $(0.00324)$ \\
\hline \multirow[t]{2}{*}{ SIZE } & & $-0.305^{\star * *}$ & $0.595^{\star * *}$ & & $-0.317^{\star * \star}$ & $0.602^{\star * *}$ \\
\hline & & $(0.00915)$ & $(0.0239)$ & & $(0.00834)$ & $(0.0271)$ \\
\hline \multirow[t]{2}{*}{ EMPLOYMENT } & & $0.281^{* * *}$ & $0.195^{\star * *}$ & & $0.286^{* * *}$ & $0.191^{* * *}$ \\
\hline & & $(0.00652)$ & $(0.00894)$ & & $(0.00575)$ & $(0.00988)$ \\
\hline \multirow[t]{2}{*}{ CASHFLOW } & & $0.0370^{* *}$ & $0.125^{\star * *}$ & & $0.0459^{\star \star \star}$ & $0.127^{\star * \star}$ \\
\hline & & $(0.0183)$ & $(0.00499)$ & & $(0.0168)$ & $(0.00560)$ \\
\hline Observations & 60,897 & 37,688 & 126,591 & 46,821 & 49,254 & 107,050 \\
\hline Fixed effects & No & No & Yes & No & No & Yes \\
\hline Year effects & Yes & Yes & Yes & Yes & Yes & Yes \\
\hline R-squared & 0.114 & 0.211 & 0.852 & 0.090 & 0.229 & 0.851 \\
\hline
\end{tabular}

Notes: Specifications 1-3 show the effects using the full sample. Specifications 4-6 exhibit the estimates for the PSM-matched sample. The control variables, described in Table 1, include Tobin's, CASHFLOW, and financial constraints, measured as CASHFLOW/FIXED ASSET, EMPLOYMENT, and CASHFLOW. In specifications 3 and 6, ETI_FINCONSTRAINTS is the triple interaction between ETI_FIRM, POST-ETI, and our measure of ETI intensity. ETI_FINCONSTRAINTS is our fixed effects triple-DiD estimator, and the OLS results follow a quantile regression approach, conditional on the financial constraints distribution. To capture the ETI effect on the profitability of financially constrained firms, the quantile OLS were performed at the lowest decile of the FIN_CONSTRAINTS distribution. Robust standard errors in parentheses; ${ }^{* *},{ }^{* *}$, and * refer to $1 \%, 5 \%$, and $10 \%$ levels of significance, respectively.

Source: Authors' construction based on IRP5 data.

The strategy of sorting firms on size exploits heterogeneity between ETI takers and, by extension, variations in ETI intensity. In particular, we split the sample between small and large firms. Columns 1 (full sample), 4, and 5 (matched sample) of Table 11 show that financially constrained firms' profitability is particularly responsive to the policy. The simple triple-DiD estimate is as large as 15.6 per cent for the full sample, and 14.1 per cent for the matched samples. There is a healthy 1.6 per cent increase in profitability observed in the matched sample using the conditional triple DiD. The ETI cost differential effect permits firms to build up cash flows, thereby relaxing borrowing constraints. Improved cash flows occasioned by higher profitability serve as an insurance against shocks to capital levels in future periods.

A firm's positive response in terms of growth, profits, and access to credit is important to improving countercyclical fiscal policy designs aimed at spurring economic expansion and creating job. Learning firms' response to the ETI is fundamental to the ongoing policy debate, but more important is learning why they respond as they do. The availability of the microdata may spur enough empirical enquiries for a comprehensive exploration of the employment policy. The current results have important macroeconomic relevance for business activity.

The results suggest that improvements in programme firms' financial conditions synchronize with other fundamental gains. Coricelli et al. (2012) maintain that financial conditions in the corporate sector affect firm performance as well as macroeconomic outcomes. Ang (2008) provides a survey of the nexus finance growth. Nevertheless, they contrast sharply with Korkeamäki (2011), who finds negligible effects of payroll tax cuts on firms' profits for a Finnish sample. However, Skedinger (2015) reports that profits increased in a subsample of firms employing young workers as a result of payroll tax cuts, though cautioning that strong conclusions regarding profits cannot be drawn owing to the small sample used in his study. Although profits often show idiosyncratic 
volatility across firms and time, the estimate of the ETI effect on firms' profits is very important, as the effect appears to be stronger for firms with liquidity problems in a developing financial market environment.

Controlling for various firm-level characteristics within the size-sorted decile, the results in Columns 1 and 2 of Table 12 show an increase in firms' debt ratios for both the full and the matched sample using fixed effect regressions. As in Saez et al. (2019), the first two columns of Table 12 use firm size as a proxy for credit constraints, and the subsequent columns employ the ratio of cash flows to long-term liabilities. Columns 1 and 2 show coefficient estimates significant according to the liquidity infusion theory. Similarly, OLS regressions show that financially constrained firms have greater LEVERAGE, attributable to the ETI. If greater access to credit allows a firm to purchase investments, many scholars concur, it heightens default risk (Bernanke et al. 1999; Coricelli et al. 2012; Kiyotaki and Moore 1997; Marcelin and Mathur 2014). Coricelli et al. (2012) discuss the point at which corporate indebtedness becomes a cause for concern. The policy's effect on profits enhances firms' balance sheets. Firms with stronger balance sheets present lower default risk, and incur lower transaction costs. Della Seta (2013), Lyandres and Palazzo (2016), and Morellec et al. (2014) link corporate cash build-ups to product market competition in the presence of financing constraints, which ultimately elevates the risk that the firm will raise costlier external finance to fund investment.

Table 12: Triple-DiD regressions on the effects of the ETI on financially constrained firms' debt capacity

\begin{tabular}{|c|c|c|c|c|c|c|}
\hline & & Eull sample & & Propensi & -score match & d sample \\
\hline & OLS & OLS & $\mathrm{FE}$ & OLS & OLS & $\mathrm{FE}$ \\
\hline ETI & $0.570^{\star \star \star}$ & 0.232 & & $0.570^{\star \star \star}$ & 0.205 & \\
\hline & $(0.00269)$ & $(0.00359)$ & & $(0.00394)$ & $(0.00409)$ & \\
\hline ETI_FINCONSTRAINTS & & & $0.0224^{* * *}$ & & & $0.0207^{* *}$ \\
\hline & & & $(0.0208)$ & & & $(0.0213)$ \\
\hline SIZE & & $-0.452^{\star \star \star}$ & $-0.717^{* \star *}$ & & $-0.495^{\star \star *}$ & $-0.710^{* \star *}$ \\
\hline & & $(0.00626)$ & $(0.0104)$ & & $(0.00671)$ & $(0.0113)$ \\
\hline Tobin's Q & & $0.0398^{\star * *}$ & $-0.0856^{\star \star \star}$ & & $0.0205^{\star \star}$ & $-0.0827^{\star \star *}$ \\
\hline & & $(0.00730)$ & $(0.00801)$ & & (0.00924) & $(0.00960)$ \\
\hline FINCONSTRAINTS & & $-0.0190^{\star \star \star}$ & $-0.0157^{\star \star \star}$ & & $-0.0196^{\star \star \star}$ & $-0.0158^{\star \star *}$ \\
\hline & & $(0.00302)$ & $(0.00273)$ & & $(0.00332)$ & $(0.00286)$ \\
\hline DIVIDENDS & & $0.818^{\star \star \star}$ & $0.0950^{\star * *}$ & & $0.797^{\star \star \star}$ & $0.0972^{* \star *}$ \\
\hline & & $(0.0114)$ & $(0.0103)$ & & $(0.0124)$ & $(0.0108)$ \\
\hline Observations & 85,665 & 64,929 & 177,281 & 62,688 & 50,163 & 148,259 \\
\hline Fixed effects & No & No & Yes & No & No & Yes \\
\hline Years effects & Yes & Yes & Yes & Yes & Yes & Yes \\
\hline R-squared & 0.628 & 0.749 & 0.934 & 0.563 & 0.745 & 0.934 \\
\hline
\end{tabular}

Notes: Specifications 1-3 show the effects using the full sample. Specifications 4-6 exhibit the estimates for the PSM sample. The control variables, described in Table 1, include Tobin's, SIZE, and financial constraints, measured as CASHFLOW/FIXED ASSET, PROFITS, and DIVIDENDS. In specifications 3 and 6, ETI FINCONSTRAINTS is the triple interaction between ETI FIRM, POST-ETI, and our measure of ETI intensity. ETI_FINCONSTRAINTS is our fixed effects triple-DiD estimator, and the OLS results follow a quantile regression approach, conditional on the financial constraints distribution. To capture the ETI effect on debt capacity of financially constrained firms, the quantile OLS were performed at the lowest decile of the

FIN_CONSTRAINTS distribution. Robust standard errors in parentheses; ${ }^{* * *}$, ${ }^{* *}$, and * refer to $1 \%, 5 \%$, and $10 \%$ levels of significance, respectively.

Source: Authors' construction based on IRP5 data. 
The results imply that the liquidity infusion induced by the policy enhances the financially challenged firm's credit worthiness ex-post. Trade-off theory predicts that some net benefits of debt financing will rise for companies with low debt but will decrease as leverage becomes high, implying that net benefits are a non-monotonic function of leverage (Coricelli et al. 2012). Starting with Kraus and Litzenberger (1973), trade-off theory holds that the optimal capital structure is a function of agency cost associated with debt, the heightened costs of financial distress as more debt adds to the firm riskiness, and benefits such as the interest tax shield. Included in the benefits of indebtedness are the disciplining effect of debt financing, and the mitigation of agency problems. Jensen (1986) propounds that the disciplining effect of debt operates through a reduction in free cash flow. Other views on the effect of indebtedness include risk-shifting (Jensen and Meckling 1976); and asset fire sales (Schleifer and Vishny 1992). Therefore, as ETI firms increase leverage, management should be concerned with amplifying the adverse effect of debt on firms. Ultimately, debt servicing and overhang weigh on leveraged firms and consume investible resources, thus preventing firms from expanding, or impeding their ability to acquire investments with positive net present value.

In view of heterogeneity across firms, firms' responses to the incumbent employment policy shock vary significantly. The relationship between the policy and investment, profitability, and debt is non-monotonic across the size spectrum, with small firms consistently responding more strongly to the policy. The non-uniformity of the response may be explained by large firms' ability to acquire resources ex-ante, and their type of endowments. With higher investment rates tied to increases in firm value (Pérez-González and Yun, 2013); higher cash-flow events enhance investment or financing decisions, and thereby firm value. Moreover, ETI firms might have found it optimal to fund additional investments with debt. Perhaps, the average programme firm, risk-neutral, is concerned with statutory tax rates and debt limit capacity. Possibly, ETI firms seek to increase capital investment by adopting more aggressive financing policies. This finance effect manifests itself in higher cash flow realizations, greater debt capacity, and possibly a lower cost of external finance for programme firms. With the ever-increasing importance of small firms in the economy, these estimates are of great relevance for policymakers.

\section{Conclusion}

Using the DiD technique, this study evaluates the effect of the Employment Tax Incentive (ETI) introduced by the South African government in 2014 on several firm-level outcomes. It uses matching models and controls for firm-level attributes, and finds that ETI firms expand significantly, experience greater profits, and have easier access to external debt. The ongoing programme is deemed economically and financially impactful. By reducing the costs of hiring a hard-to-employ group, ETI appears simultaneously to unleash some economic potentials. At the first decile of the size distribution, programme firms post higher profits, thus boosting net worth and serving as an insurance in the event of negative shocks depleting net worth in subsequent periods.

Although the results obtained using matching models are appealing, the reader should be reminded that they assume that unobserved firm-level characteristics are immaterial to matching ETI and non-ETI firms. However, the results, notwithstanding their limitations, evidence how a government programme affects firms' performance, and by extension their growth. More importantly, smaller programme firms' greater access to finance is relevant for investment purchases in many countries with imbalances in the labour market and dealing with sluggish growth. The ease of access to credit is indicative of financial development, and is of great relevance for countries seeking to develop their financial market to allow firms easier access to investible 
resources in order to finance growth. Nonetheless, leveraging the firm may induce negative effects in the long run. At some point corporate indebtedness becomes a cause for concern, since the adverse effects of heightened leverage overtake its benefits as debt needs to be serviced, and debt overhang may weigh down the firm's ability to purchase productive investment.

Methodologically, we were able to match on pre-treatment attributes and populate a sample of non-ETI firms similar to their ETI peers. Nevertheless, the propensity-score and attribute-based matching models rely on the assumption that the effects of unobservables are not pertinent to estimating the treatment effects (Lawrence et al. 2011). The administrative data show some limitations in terms of non-fraudulent and continuing claims. We were unable to consider some relevant firm attributes in view of the lack of useful availability thereof. Data management required imposing some restrictions which, admittedly, cannot be viewed as bias-free. Although such limitations do not affect firms' treatment status, resulting in minimal impacts on the estimates, further research is needed to confirm the effect of the policy on firms. Consequently, this study does not resolve the fundamental question of the effect of the ETI policy on firms. It only provokes the debate by putting forward indicative evidence of the underlying effect. It encourages further inquiries to pinpoint the effect of such an important policy initiative, with ramifications for firms' finances as well as for fiscal and labour market policies. 


\section{References}

Anderson, P., and D.B. Meyer (1997). 'Unemployment Insurance Takeup Rates and the After-Tax Value of Benefits'. Quarterly Journal of Economics, 112(3): 913-37.

Anderson, P., and D.B. Meyer (2000). 'The Effects of the Unemployment Insurance Payroll Tax on Wages, Employment, Claims and Denials'. Journal of Public Economics, 78: 81-106.

Ang, J.B. (2008). 'A Survey of Recent Developments in the Literature of Finance and Growth'. Journal of Economic Surveys, 22: 536-76.

Armenter, R., and V. Hnatkovska (2011). 'The Macroeconomics of Firms' Savings'. Working Paper 12-1. Philadelphia, PA: Federal Reserve Bank of Philadelphia.

Balasubramanyan, L., and R. Mohan (2010). 'How Well Is Productivity Being Priced'? Journal of Economics and Finance, 34: 415-29.

Bennmarker, H., E. Mellander, and B. Öckert (2009). 'Do Regional Payroll Tax Reductions Boost Employment'? Labour Economics, 16: 480-89.

Bernanke, B., M. Gertler, and S. Gilchrist (1999). 'The Financial Accelerator in a Quantitative Business Cycle Framework'. In J. Taylor and M. Woodford (eds), Handbook of Macroeconomics, Volume I. Amsterdam: Elsevier.

Bishop, H.J., and M. Montgomery (1993). 'Does the Targeted Jobs Tax Credit Create Jobs at Subsidised Firms?' Industrial Relations, 32(3): 289-306.

Bishop, J. (1981). 'Employment in Construction and Distribution Industries: The Impact of the New Jobs Tax Credit'. In S. Rosen (ed.), Studies in Labor Markets. Chicago: The University of Chicago Press.

Bryson, A., R. Dorsett, and S. Purdon (2002). 'The Use of Propensity Score Matching in the Evaluation of Active Labour Market Policies'. Working Paper 4. London: HMSO.

Caglayan, M., and F. Demir (2014). 'Firm Productivity, Exchange Rate Movements, Sources of Finance, and Export Orientation'. World Development, 54: 204-19.

Card, D., and A.B. Krueger (1995). 'Myth and Measurement: The New Economics of the Minimum Wage'. Princeton, NJ: Princeton University Press.

Carpenter, R.E., and B.C. Petersen (2002). 'Is the Growth of Small Firms Constrained by Internal Finance?' Review of Economics and Statistics, 84(2): 298-309.

Chetty, R., and E. Saez (2005). 'Dividend Taxes and Corporate Behavior: Evidence from the 2003 Dividend Tax Cut'. Quarterly Journal of Economics, 120(3): 791-833.

Coricelli, F., N. Driffield, S. Pal, and I. Roland (2012). 'When Does Leverage Hurt Productivity Growth? A Firm-Level Analysis'. Journal of International Money and Finance, 31: 1674-94.

Cram, D., V. Karan, and I. Stuart (2009). 'Three Threats to Validity of Choice-Based and Matched Sample Studies in Accounting Research'. Contemporary Accounting Research, 26(2): 477-516.

De Lannoy, A., L. Graham, L. Patel, and M. Leibbrandt (2018). What Drives Youth Unemployment and What Interventions Help? A Systematic Overview of the Evidence and $a$ Theory of Change. High-Level Overview Report. Rondebosch: REDI $3 \times 3$.

Dehejia, R. (2005). 'Practical Propensity-Score Matching: A Reply to Smith and Todd'. Journal of Econometrics, 125(1-2): 355-64. 
Dehejia, R., and S. Wahba (1999). 'Causal Effects in Nonexperimental Studies: Reevaluating the Evaluation of Training Programs'. Journal of the American Statistical Association, 94(4): 1053-62.

Dehejia, R., and S. Wahba (2002). 'Propensity Score-Matching Methods for Nonexperimental Causal Studies'. The Review of Economics and Statistics 84(1): 151-61.

Della Seta, M. (2013). ‘Cash and Competition'. Working paper. Tilburg: Tilburg University.

Desai, M.A., C.F. Foley, and J.R. Hines (2004). 'A Multinational Perspective on Capital Structure Choice and Internal Capital Markets'. Journal of Finance, 59(6): 2451-87.

Draca, M., S. Machin, and J. Van Reenen (2011). 'Minimum Wages and Firm Profitability'. American Economic Journal: Applied Economics, 3(1): 129-51.

Dwyer, D.W. (2001). 'Plant-Level Productivity and the Market Value of a Firm'. Working Papers 01-03. Washington, DC, and Suitland, MD: Center for Economic Studies, US Census Bureau.

Ebrahim, A., M. Leibbrandt, and V. Ranchhod (2017). 'The Effects of the Employment Tax Incentive on South African Employment'. WIDER Working Paper 2017/5. Helsinki: UNUWIDER.

Faccio, M., and J. Xu (2015). 'Taxes and Capital Structure'. Journal of Financial and Quantitative Analysis, 50: 277-300.

Fagiolo, G., and A. Luzzi (2006). 'Do Liquidity Constraints Matter in Explaining Firm Size and Growth? Some Evidence from the Italian Manufacturing Industry'. Industrial and Corporate Change, 15(1): 1-39.

Fan, J.P.H., S. Titman, and G. Twite (2012). 'An International Comparison of Capital Structure and Debt Maturity Choices'. Journal of Financial and Quantitative Analysis, 47(1): 23-56.

Fazzari, S.R., G. Hubbard, and B. Petersen (1988). 'Financing Constraints and Corporate Investment'. Brookings Papers on Economic Activity, 1: 141-206.

Galasso, E., M. Ravallion, and A. Salvia (2001). 'Assisting the Transition from Workfare to Work: A Randomized Experiment'. Policy Research Working Paper 2738. Washington, DC: World Bank.

Girma, S, H. Görg, E. Strobl, and F. Walsh (2008). 'Creating Jobs through Public Subsidies: An Empirical Analysis'. Labour Economics, 15(6): 1179-99.

Hamersma, S. (2008). 'The Effects of an Employer Subsidy on Employment Outcomes: A Study of the Work Opportunity and Welfare-to-Work Tax Credits'. Journal of Policy Analysis and Management, 27(3): 498-520.

Jensen, M.C. (1986). 'Agency Costs of Free Cash Flow, Corporate Finance, and Takeovers'. American Economic Review, 76(2): 323-29.

Jensen, C.M., and H.W. Meckling (1976). 'Theory of the Firm: Managerial Behavior, Agency Costs and Ownership Structure'. Journal of Financial Economics, 3(4): 305-60.

Kaplan, S., and L. Zingales (1995). 'Do Financing Constraints Explain Why Investment Is Correlated with Cash Flow'? NBER Working Paper 5267. Cambridge, MA: National Bureau of Economic Research (NBER).

Kaplan, N.S., and L. Zingales (1997). 'Do Investment-Cash Flow Sensitivities Provide Useful Measures of Financing Constraints'? Quarterly Journal of Economics, 112(1): 169-215

Katz, K.L. (1996). 'Wage Subsidies for the Disadvantaged'. NBER Working Paper 5679. Cambridge, MA: NBER. 
Katz, K.L. (1998). 'Wage Subsidies for the Disadvantaged'. In R.B. Freeman and P. Gottschalk (eds), Generating Jobs: How to Increase Demand for Less Skilled Workers. New York: Russell Sage Foundation.

Kaunitz, N., and J. Egebark (2019). 'Payroll Taxes and Firm Performance'. Working Paper 1175. Stockholm: Institute of Industrial Economics (IFN).

Kiyotaki, N., and J. Moore (1997). 'Credit Cycles'. Journal of Political Economy, 105(2): 211-48.

Korkeamäki, O. (2011). 'The Finnish Payroll Tax Cut Experiment Revisited'. Working Paper 22. Helsinki: Government Institute for Economic Research Finland (VATT).

Korkeamäki, O., and R. Uusitalo (2009). 'Employment and Wage Effects of Payroll Tax Cut: Evidence from a Regional Experiment'. International Tax and Public Finance, 16: 753-72.

Kraus, A., and H.R. Litzenberger (1973). 'A State-Preference Model of Optimal Financial Leverage'. Journal of Finance, 28(4): 911-22.

Lawrence, A., M. Minutti-Meza, and P. Zhang (2011). 'Can Big 4 versus Non-Big 4 Differences in Audit-Quality Proxies Be Attributed to Client Characteristics?’ Accounting Review, 86(1): 259_ 86.

Levinsohn, J., and T. Pugatch (2014). 'Prospective Analysis of a Wage Subsidy for Cape Town Youth'. Journal of Development Economics, 108: 169-83.

Levinsohn, J., N. Rankin, G. Roberts, and V. Schöer (2014). 'Wage Subsidies and Youth Employment in South Africa: Evidence from a Randomised Control Trial'. Stellenbosch Economic Working Paper 02/14: Stellenbosch: Department of Economics and the Bureau for Economic Research, University of Stellenbosch.

Li, K., and N.R. Prabhala (2007). 'Self-Selection Models in Corporate Finance'. In B.E. Eckbo (ed), Handbook of Corporate Finance, Volume 1. Amsterdam: Elsevier.

Lyandres, E., and B. Palazzo. (2016). 'Cash Holdings, Competition, and Innovation'. Journal of Financial and Quantitative Analysis, 51(6): 1823-61.

Lyandres, E. (2007). 'Costly External Financing, Investment Timing, and Investment-Cash Flow Sensitivity'. Journal of Corporate Finance, 13: 959-80.

Marcelin, I., and I. Mathur (2014). 'Financial Development, Institutions, and Banks'. International Review of Financial Analysis, 31: 25-33.

Marcelin, I., and I. Mathur (2015). 'Privatization, Financial Development, Property Rights and Growth'. Journal of Banking \& Finance, 50: 528-46.

Marcelin, I., and I. Mathur (2016). 'Financial Sector Development and Dollarization in Emerging Economies'. International Review of Financial Analysis, 46: 20-32.

Mathur, I., and I. Marcelin (2014). 'Unlocking Credit'. In J.A. Batten and N.F. Wagner (eds), Risk Management Post Financial Crisis: A Period of Monetary Easing (Contemporary Studies in Economic and Financial Analysis, Volume 96). Bingley: Emerald Group Publishing Limited.

Mathur, I., and I. Marcelin (2015). 'Institutional Failure or Market Failure?' Journal of Banking \& Finance, 52: 266-80.

Mbeki, T. (2003). 'Address to the National Council of Provinces, 11 November 2003'. Available at http://www.sarpn.org.za/documents/d0000830/index.php (accessed 28 May 2019).

Morellec, E., B. Nikolov, and F. Zucchi (2014). 'Competition, Cash Holdings, and Financing Decisions'. Swiss Finance Institute Research Paper 13-72. Zurich: Swiss Finance Institute. 
Mühlau, P., and W. Salverda (2000). 'Employment Effects of Low-Wage Subsidies: The Case of SPAK'. In W. Salverda, C. Lucifora, and B. Nolan (eds), Policy Measures for Low-Wage Employment in Europe. Cheltenham: Edward Elgar.

Murphy, K.J. (2007). 'The Impact of Unemployment Insurance Taxes on Wages'. Labour Economics, 14(3): 457-84.

National Treasury (2011). 'Confronting Youth Unemployment: Policy Options for South Africa'. Discussion paper prepared for public comment. Pretoria: National Treasury.

Oliveira, B., and A. Fortunato (2006). 'Firm Growth and Liquidity Constraints: A Dynamic Analysis'. Small Business Economics, 27(2): 139-56.

Pérez-González, F., and H. Yun (2013). 'Risk Management and Firm Value: Evidence from Weather Derivatives'. Journal of Finance, 68(5): 2143-76.

Perloff, M.J, and M.L. Wachter (1979). 'The New Jobs Tax Credit: An Evaluation of the 1977-78 Wage Subsidy Program'. American Economic Review, 69(2): 173-79.

Saez, E., B. Schoefer, and D. Seim (2019). 'Payroll Taxes, Firm Behavior, and Rent Sharing: Evidence from a Young Workers' Tax Cut in Sweden'. American Economic Review, 109(5): 1717 63.

Schleifer, A., and W.R. Vishny (1992). 'Liquidation Values and Debt Capacity: A Market Equilibrium Approach'. Journal of Finance, 47(4): 1343-66.

Seekings, J. (2007). 'Poverty and Inequality after Apartheid'. Paper prepared for the second 'After Apartheid' Conference. Published as CSSR Working Paper 200. Cape Town: Centre for Social Science Research (CSSR), University of Cape Town. Available at: http:/ /www.cssr.uct.ac.za/ sites/default/files/image_tool/images/256/files/pubs/WP200.pdf (accessed 29 May 2019).

Silva, F., and Carreira, C. (2012). 'Measuring Firms' Financial Constraints: A Rough Guide'. Notas Económicas, 36: 23-46.

Skedinger, P. (2015). 'Employment Effects of Union-Bargained Minimum Wages: Evidence from Sweden's Retail Sector'. International Journal of Manpower, 36(5): 694-710.

Statistics South Africa (2016). 'Quarterly Labour Force Survey Quarter 4: 2016'. Statistical Release PO211. Pretoria: Statistics SA. Available at: http://www.statssa.gov.za/publications/P0211/ P02114thQuarter2016.pdf (accessed 28 May 2019).

Yagan, D. (2015). 'Capital Tax Reform and the Real Economy: The Effects of the 2003 Dividend Tax Cut'. American Economic Review, 105(12): 3531-63.

Zwick, E., and Mahon, J. (2017). 'Tax Policy and Heterogeneous Investment Behavior: Dataset'. American Economic Review, 107(1): 217-48. 